\title{
Journalist i grænselandet
}

\section{Af FLEMMING NiELSEN}

Journalist Flemming Nielsen, Broager, er mest kendt for sine mange år på Radio Syd 1983-2008. Han var bl.a. vært for de populære programmer "Grænseland «, "Grænseland Europa " og »To generationer «. Det journalistiske håndværk lærte han på Vestkysten i Tønder og Sønderjyden i Sønderborg. Flemming Nielsen fortæller om sine mange år som journalist i grænselandet, om sine arbejdspladser - og om de mennesker, han mødte.

Jeg trådte ind på dagbladet Vestkystens redaktion på Torvet $\mathrm{i}$ Tønder den 1. juli 1965. Jeg var 17 år, tre måneder og ni dage gammel, jeg havde en funklende ny realeksamen $i$ bagagen - og var dårligt nok tør bag ørerne. Jeg havde ikke meget begreb om, hvad journalistik egentlig var for noget. Bevares, jeg var ret god til at skrive dansk stil. Og jeg havde med stor interesse læst Jydske Tidende, fra jeg begyndte i 1. klasse på Kliplev Skole, suppleret med alle mulige andre aviser i barndoms- og ungdomsårene, f.eks. Aktuelt og Dagens Nyheder. Lysten til at komme $\mathbf{i}$ gang fejlede $\mathbf{i}$ hvert fald ikke noget. Men det var altså ikke med en »Her-kommer-jeg ... gem-lige-en-fire-spaltet-påforsiden-til-mig-i-morgen«-attitude, jeg gjorde min entré på Vestkysten.

Jeg blev modtaget af lokalredaktør Edvard Sørensen. Han var - mildt sagt - meget lidt talende. Ja, faktisk virkede han en smule genert. Men når blot medarbejderne fik fyldt spalterne og ikke stillede alt for mange spørgsmål, var redaktøren glad og tilfreds. Jeg husker ikke, om jeg havde mødt lokalredaktøren tidligere, men det er muligt. Før jeg begyndte på avisen som »redaktionsassistent «, havde jeg nemlig fungeret som lokal meddeler med udgangspunkt i Jejsing øst for Tønder. Her var min far stationsmester, og her boede jeg et par år hos mine forældre.

Når jeg bladrer i mine allerførste scrapbøger, får jeg bekræftet, at jeg i min første tid hverken var dybdeborende eller kritisk journalist. Snarere registrerende. Nogle af de små gulnede udklip fortæller, at Jejsing B-hold i håndbold tabte 10-11 i Øster Højst. Og endnu værre gik det med herre-mesterrækkeholdet, der fik smæk af Ellehus-Emmerske med hele 8-13. Det var eksklusive nyheder for Vestkystens læsere! Ingen begivenheder i Jejsing og omegn var så små, at de ikke 
kunne finde vej til avisens spalter. Blandt andet var jeg som meddeler med til maskindemonstration hos Lützens Maskinforretning, hvor den nyeste mejetærsker blev beundret af egnens landmænd.

Modtagelseskomitéen, da jeg gjorde min entré på Vestkysten, bestod ud over redaktør Sørensen af Frieda Matzen og Aage Lomholt Pedersen, henholdsvis kontorassistent og journalist. Frieda passerede i marts 201046 årsdagen for sin ansættelse, så hun kender tøndringerne og deres familier og historie til fingerspidserne. Ja - $\mathrm{i}$ virkeligheden var hun et stillesiddende leksikon, dér på sin kontorstol. Her tog hun imod annoncer - og her måtte hun for Gud ved hvilken gang forsikre fru Hansen på Ribe Landevej om, at "avisbudet nok skulle huske hende $i$ eftermiddag, når hun nu blev snydt $i$ går«. Frieda var guld værd for en stor knægt som mig, der havde alt at lære.

\section{Med »æ rutebil«}

"Ska' då te' Høwe - så gå ba'e nee å Tynne Øst å tej æ rutebil", forklarede Frieda mig. Og så dappede jeg til Højer med »æ rutebil«. Frieda forsøgte også at lære mig at skifte farvebånd på skrivemaskinen - og med sit aldrig svigtende humør fik hun overbevist mig om, når noget drillede, "at det da var meget sværere at være jetpilot end journalist«. I mine år ved Danmarks Radio i Aabenraa tyede jeg også til Frieda indimellem, når jeg var i tidnød og havde brug for en konkret oplysning fra Tønder og omegn her og nu.

Aage Lomholt Pedersen var en anelse mere snakkesalig end lokalredaktøren. Lomholt gik - og kørte - sine egne veje. I de fem måneder, jeg arbejdede på Vestkysten, lærte jeg ham dårligt nok at kende. Men han var venlig og hjælpsom. Jeg fandt aldrig ud af, om hans kildenet var særlig godt i Aventoft, men næsten dagligt startede han bilen og smuttede over grænsen for en stund.

Selv havde jeg det lidt svært med at komme omkring. Som 17-årig havde jeg kun cyklen og de offentlige transportmidler til rådighed. Indimellem kørte jeg i bus, men jævnligt trampede jeg i pedalerne, når jeg skulle til Øster Højst, Møgeltønder eller Bylderup-Bov. Jeg husker tydeligt en tur til Øster Højst, hvor jeg besøgte brændeskærer Martin Tastesen og beskrev hans arbejde. Han havde 17 års erfaring og kom vidt omkring med sin motorsav, rundsav og kvashugger.

»Da jeg arbejdede på en gård ved Lille Jyndevad, kom jeg til at holde med traktoren i Tyskland og saven i Danmark«, fortalte Martin 
Tastesen. Som et bevis på, at han havde været i nærkontakt med en savklinge, fremviste han sin venstre hånd. På den sad 1, 2, 3, 4 fingre. Tommelen manglede. Artiklen fra Øster Højst - illustreret af juniorreporterens to fotos - var forsynet med min første signatur, »- ming. «

Det var ikke ligefrem inspiration og gode ideer, jeg kunne øse af på redaktionen. Derfor måtte jeg hjælpe mig selv, når jeg manglede stof. Jeg gik på jagt efter spændende firmaer i telefonbogen, og så startede jeg min helt egen lille serie med små firmaportrætter. Fra mineralvandsfabrikken "Guldhorn « kunne jeg berette for læserne, at der året før - i 1964 - var produceret ikke færre end 1,8 millioner flasker sodavand. Indehaveren, Harald Sauer, betroede mig, at man fint kunne konkurrere med de store bryggerier. Det var straks værre med de små konkurrenter, som der var skudt mange op af.

Også parfumefirmaet »Dralle« i Tønder fik besøg af den unge reporterspire. Her fremstillede man blandt andet shampoo, brillantine og frisercreme. Direktør Christian Lausten demonstrerede for mig, hvordan man tog prøver af produkterne - og den dag i dag ved jeg ikke, hvorfor det kendte tyske firma, "Dralle«, havde valgt netop Tønder som placering for den eneste filial i Danmark.

Mange af mine artikler blev illustreret af fotos taget af pressefotograf Helmuth Christensen. Indimellem drog jeg dog alene af sted på en opgave - og så måtte jeg selv tage billeder. Ikke sjældent lykkedes det med ganske fint resultat, og så afleverede jeg filmen hos firma "Brødrene Løkke", der var nabo til Vestkysten. Ofte var det Karen Ahrenkiel, der fremkaldte mine billeder. Hun begyndte senere - med stor succes - at arbejde som selvstændig fotograf.

\section{The Mods i æ kjølle}

Som 17-årig midt i 60'erne kunne man næsten ikke undgå at interessere sig for pigtrådsmusik. Også i Tønder blev denne musikform praktiseret med stor entusiasme, blandt andet af fire ungersvende: Benny, Peter, Poul Erik og "Møsse «, der var døbt Svend Ove. Sammen udgjorde de The Mods, der havde fast spillested i "Kælderen« ("æ kjølle«) på Skibbrogade. Når jeg i dag - som en gammel rotte i faget tænker tilbage på mit interview med de fire unge, kan jeg kun - med et lille smil om munden - sige: Sådan ville jeg ikke interviewe i dag ... Eksempel: 
- Hvor havde I Jeres debut?

- Det var i Ungdomsborgen her i Tønder.

- Var I nervese?

- Benny: - Mine knæskaller dirrede om kap.

- Møsse: Kun en smule nervøs.

- Jeres største succes til dato:

- Det var i Star Club i Flensborg, hvor vi spillede hver weekend $i$ en måned $-\mathbf{i}$ bare tæer ...

- Hvorfor er I ikke langhårede?

- Det tillader vort arbejde ikke.

Hele artiklen er bygget op på korte spørgsmål og svar - en mildt sagt alternativ måde at interviewe på set med nutidige journalist-briller. Men dengang vidste jeg ikke bedre. Og hverken på lokalredaktionen eller hovedredaktionen i Esbjerg, hvor chefredaktør Knud Ree tronede, ulejligede man sig med at sætte mig ind i blot det mest elementære inden for journalistikken.

\section{»Toni«s fortjeneste}

Skal jeg være ærlig, var jeg nok en smule stolt over at »arbejde som journalist«. Og det gav status. Tre af gutterne i Jejsing, Svend Erik, Andreas og Carl Ernst, hyggede sig sammen med andre af byens unge med at køre ræs på nogle gamle motorcykler på en lille uautoriseret motorbane på Jejsing Bakkeøs sydlige skråning. Også denne aktivitet fortalte jeg om i Vestkysten i en artikel med et to-spaltet foto, som jeg selv tog. Jo, det var skam ikke så tosset at kende en reporter på 17 år. Var man heldig, kom man ligefrem i »æ blaj« - med billede.

At være ansat på Vestkysten, var ensbetydende med mange arbejdsdage og fă fridage. Når jeg en sjælden gang havde tid til at handle $i$ Calles Supermarked i Jejsing, spurgte juniorchefen, Antoni Andresen, interesseret til min gøren og laden. "Toni«, der senere grundlagde "Calle-butikkerne« syd for grænsen, var den direkte årsag til, at jeg fik job på Vestkysten. Han havde selv en drøm om at skabe sig en karriere som journalist, men det ville hans far, Carl Andresen, ikke høre tale om. Toni skulle videreføre firmaet engang. Og det må man jo sige, han har klaret godt. Men når journalistens metier ikke måtte blive hans, kunne Toni jo altid hjælpe en anden ind i faget. Og det blev så mig. Antoni Andresen, som jeg er megen tak skyldig, kom 


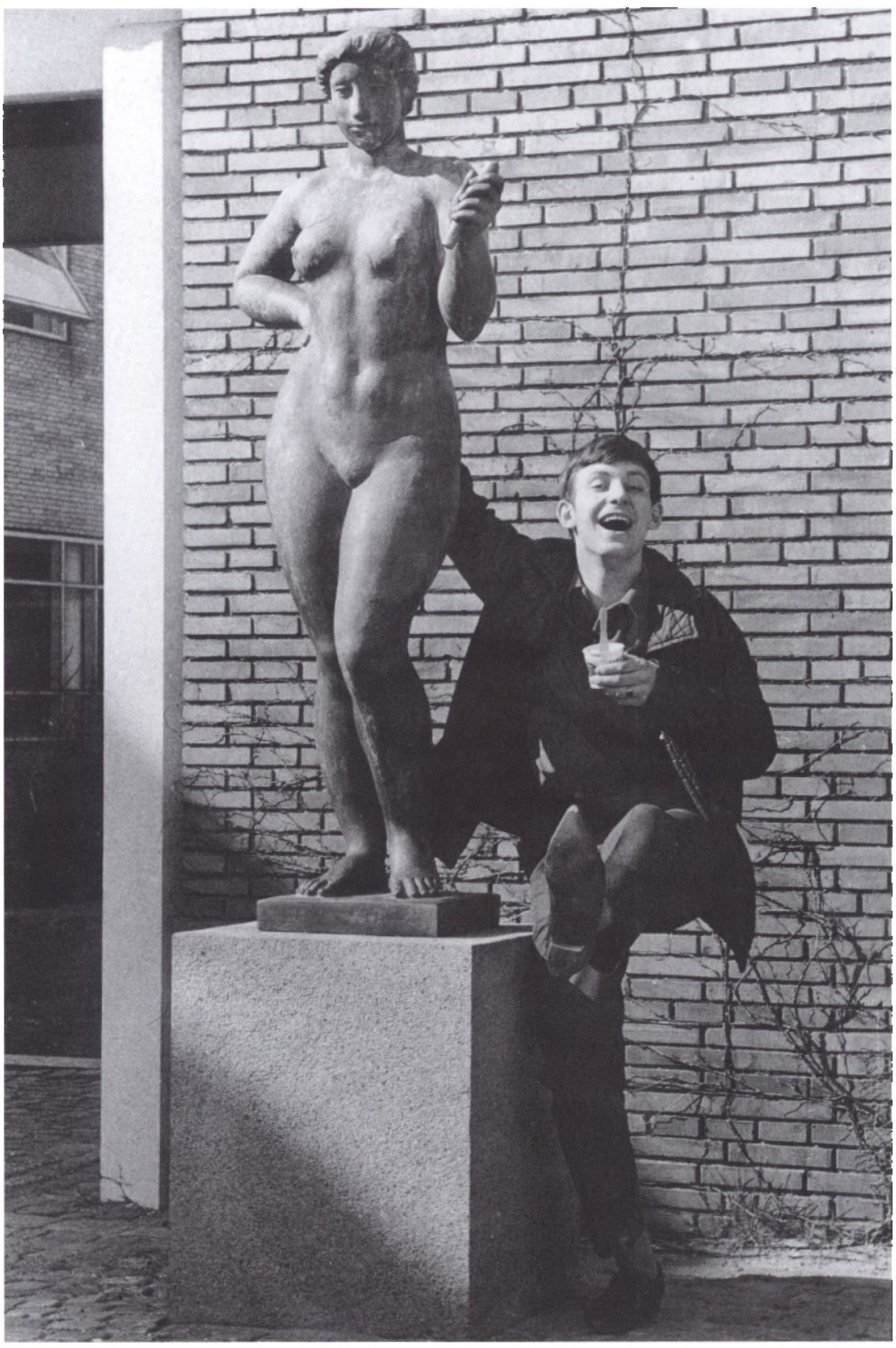

Den unge reporterspire Flemming Nielsen med spidse sko, rock'n'roll-attitude og et fast greb om det væsentlige, fotograferet foran Idrætshøjskolen $i$ Sonderborg $i 1967$. Foto $i$ prizateje. 
godt ud af det med lokalredaktør Edvard Sørensen. Og Sørensen opgav på forhånd at indvende noget, da Andresen foreslog ham at ansætte »stationsmester Nielsens søn i Jejsing «. Antoni Andresen var allerede i sine yngre dage dygtig til at få sin vilje. Det tror jeg forresten, han stadig er. Selvom "Calle« $\mathbf{i} 2010$ blev afhændet til Fleggaard.

På hjemmefronten - hos mine forældre, Dagmar og Evald Nielsen var der lutter opbakning til min drøm om at blive journalist. I begyndelsen var de nok en smule overraskede over, at deres yngste sen ville gå dén vej. Han havde jo altid snakket om, at han ville ind til politiet. Og der var ikke andre journalister i familien. Men når det nu var hans ønske, ja - hvorfor så ikke?

\section{DDR-flygtningen Klaus Uecker}

Min måske mest interessante opgave i 1965 på Vestkysten - set med datidens briller - var mit interview med en 25-årig østtysk flygtning, Klaus Uecker. Han berettede om den grå og trøstesløse hverdag i DDR og om, hvordan han undervejs fra én østberlinsk station til en anden passerede gennem Vestberlin:

- "Jeg holdt fast ved min kuffert og var klar til at springe af ved første station efter Friedrichstrasse. Inden toget standsede, så jeg en østtysk politibetjent stå ved døren, og jeg troede, at hele planen var gået $\mathrm{i}$ vasken. Til min store forbavselse foretog han sig ikke noget, da jeg sprang mod udgangen. Tværtimod råbte han 'Hals- und Beinbruch', altså 'held og lykke'. Jeg var nu i friheden«, fortalte Klaus Uecker, der her i 1965 boede hos en ven i Tinglev, men havde planer om at slå sig ned i Tønder.

Disse linjer om mine tidlige journalistår skrives fredag den 5. februar 2010 ved 13-tiden - og efter at have genlæst min artikel med Klaus Uecker, beslutter jeg at "Google« ham på internettet. Det lykkedes mig at finde en række oplysninger om ham. Men desværre også en dødsannonce på »afdøde.dk«. Og netop her klokken 13.00 på denne 5. februar bisættes Klaus A.K. Uecker fra Rise Kirke ved Rødekro. Jeg har ikke læst artiklen siden 1965, altså for over 44 år siden. Og så præcis på dagen, hvor jeg genopfrisker mødet med den unge flygtning fra DDR, bisættes han i sin nye hjemstavn, Sønderjylland. En mildt sagt besynderlig tilfældighed.

Faktisk fandt jeg ud af, at Klaus Uecker, der spillede bas, i 1966 blev medlem af Tommyguns, hvis medlemmer jeg også interviewede i 


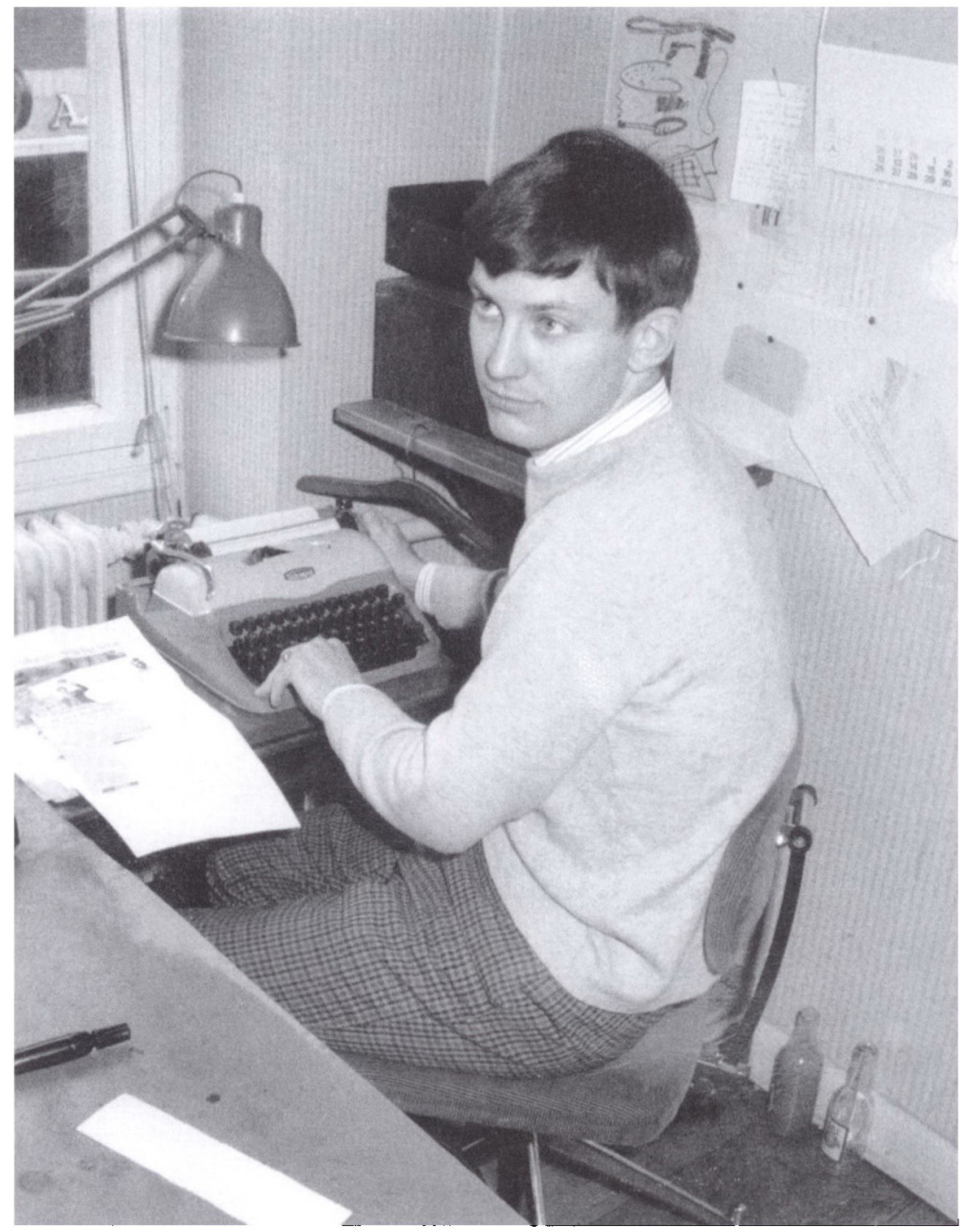

Efter en tid som redaktionsassistent på Vestkystens lokalredaktion $i$ Tonder blev Flemming Nielsen den 1. april 1966 journalistelev på den socialdemokratiske avis Sonderjyden $i$ Sønderborg. Det vigtigste arbejsredskab var skrivemaskinen. Foto $i$ privateje.

1965. Efter at Tommyguns gik i opløsning i 1967, spillede Klaus Uecker i grupper som Luckies, Four Silgettos og Silverboys, så han blev et kendt 
ansigt i sønderjysk musikliv inden for populærmusikken. Han akkompagnerede også bl.a. Dorthe Kollo og Birthe Kjær. I Four Silgettos afløste han i øvrigt min bror, Anker Nielsen.

\section{Fra Vestkysten til Sønderjyden - og fra asken i ilden}

Da jeg havde snuset til journalistikken i nogle måneder, fik jeg mere og mere lyst til at blive "rigtig “ journalist. Men på Vestkysten i Tønder var der aldrig tale om, at min ansættelse som redaktionsassistent skulle »opgraderes« til journalistelev året efter, når jeg fyldte 18 år $\mathrm{i}$ marts og, i hvert fald hvad alderen angik, ville kunne få elevkontrakt. Men der var måske andre muligheder.

Siden min tidlige barndom havde jeg interesseret mig meget for al slags sport, og jeg har selv spillet venstre wing på diverse fodboldhold: Kliplev, Hovslund, Jejsing, Rødekro og Augustenborg. Denne interesse fik de nys om på den socialdemokratiske avis i Sønderborg, Sønderjyden, der netop stod og skulle bruge en sportsmedarbejder efter John Pilegaard. Han var på vej til at skifte til Vestkystens hovedredaktion i Esbjerg. En kollega på Sønderjydens redaktion i Tønder smed en føler ud - og hun orienterede hovedredaktionen om, at jeg sikkert kunne lokkes til den alsiske metropol med udsigten til en elevkontrakt som gulerod.

En dag i det sene efterår 1965 indfandt jeg mig derfor på redaktionen i Jernbanegade i Sonderborg. Her blev jeg mødt af blandt andre redaktionssekretær Sigfred Homann Jespersen, som jeg skulle få meget at gøre med i min senere journalisttilværelse. Selve ansættelsessamtalen førte jeg med chefredaktør Kristian Bjerregaard Jessen. Der var ingen store knaster, der skulle overvindes, og vi blev hurtigt enige om de væsentligste ting: Ansættelse fra 1. december som redaktionsassistent - med særligt ansvar for sportssiderne, men med allround-opgaver på linje med de "rigtige « journalistelever. Lønposen skulle man dog kigge godt efter for at få øje på. Fra 1. april 1966 skulle jeg så have elevkontrakt med A-pressen - og sådan blev det. Jeg tog afsked med marskbyen Tønder og mors kødgryder derhjemme i Jejsing - og det lykkedes mig at leje et lille hummer på Dybbøl Banke. Her boede jeg dør om dør med kollega Flemming Christiansen fra Sonderjyden. Han var senere ansat på blandt andet TV-Avisen i en lang årrække.

Det var som at komme fra asken i ilden at flytte fra Vestkysten til 
Sønderjyden. I Tønder blev mine manuskripter kun sjældent gennemlæst - og det medførte naturligvis, at jeg ikke fik den vejledning og rådgivning, som enhver nybegynder har brug for. Det havde til følge, at mine værste sproglige unoder blomstrede og formerede sig i stedet for at blive luget ud. Men det blev de - godt og grundigt - på Sønderjyden. Sigfred Jespersen var en skrap læremester. Ved hjælp af en rød tuschpen og en kuglepen forvandlede han mine maskinskrevne manuskripter til røde, ulæselige plamager. Disse manuskripter kunne ikke afleveres til maskinsætterne. Så havde de formentlig nedlagt arbejdet. I stedet måtte jeg skrive artiklerne om. Efterhånden fik jeg dog banket en masse journalistisk børnelærdom ind i hovedet, f.eks. at man ikke AFholder, men holder et møde, og at det væsentlige i artiklen skal stå i overskriften og indledningen - og ikke til sidst.

På Sønderjyden var vi en broget skare journalister. I flæng husker jeg fra hovedredaktionen Heinz Andresen, Poul Hartvig, Erik Staffeldt, Espen Bull Nielsen, Kaj Olsen, Erich Kneiding, Helga Hoffmann, Lone Pedersen, Ernst Wittrup og Peter Brøndahl. I Aabenraa herskede Clement Larsen-Ledet (gift med borgmester Camma) bistået af Arne Thing - og senere Jens Kodal. Redaktionerne i henholdsvis Tønder og Haderslev blev ledet af Arne Tillitze Hansen og Johannes Larsen - og i Nordborg regerede Benny Siewertsen og senere Orla Nielsen.

Sønderborg var en af de provinsbyer, der havde flest avisredaktioner, nemlig fem. Foruden Sønderjyden, der havde hovedredaktion i byen og udkom om eftermiddagen, havde Jydske Tidende, Der Nordschleswiger, Dannevirke og Flensborg Avis redaktioner i byen. Dannevirkes afdeling i Sønderborg hed Dybbøl-Posten.

\section{Nyhederne tikkede ind på fjernskriveren}

Selvom jeg altså først efter fire måneder på Sønderjyden fik elevkontrakt, havde jeg fra begyndelsen ansvaret for avisens sportssider. I det daglige rettede jeg de sportstelegrammer fra Ritzau til, som tikkede ind på fjernskriveren. I min elevtid end ikke drømte vi om computere, så døgnet igennem fik vi tilført nyheder fra den fjerne og nære verden på fjernskriver. $\mathrm{Og}$ alt andet brugte vi skrivemaskine til.

Der skulle også skrives foromtaler til forskellige håndbold- og fodboldkampe, og om sommeren troppede jeg troligt op på stadion til Sønderborg Boldklubs hjemmekampe. Desværre nåede SB aldrig sær- 


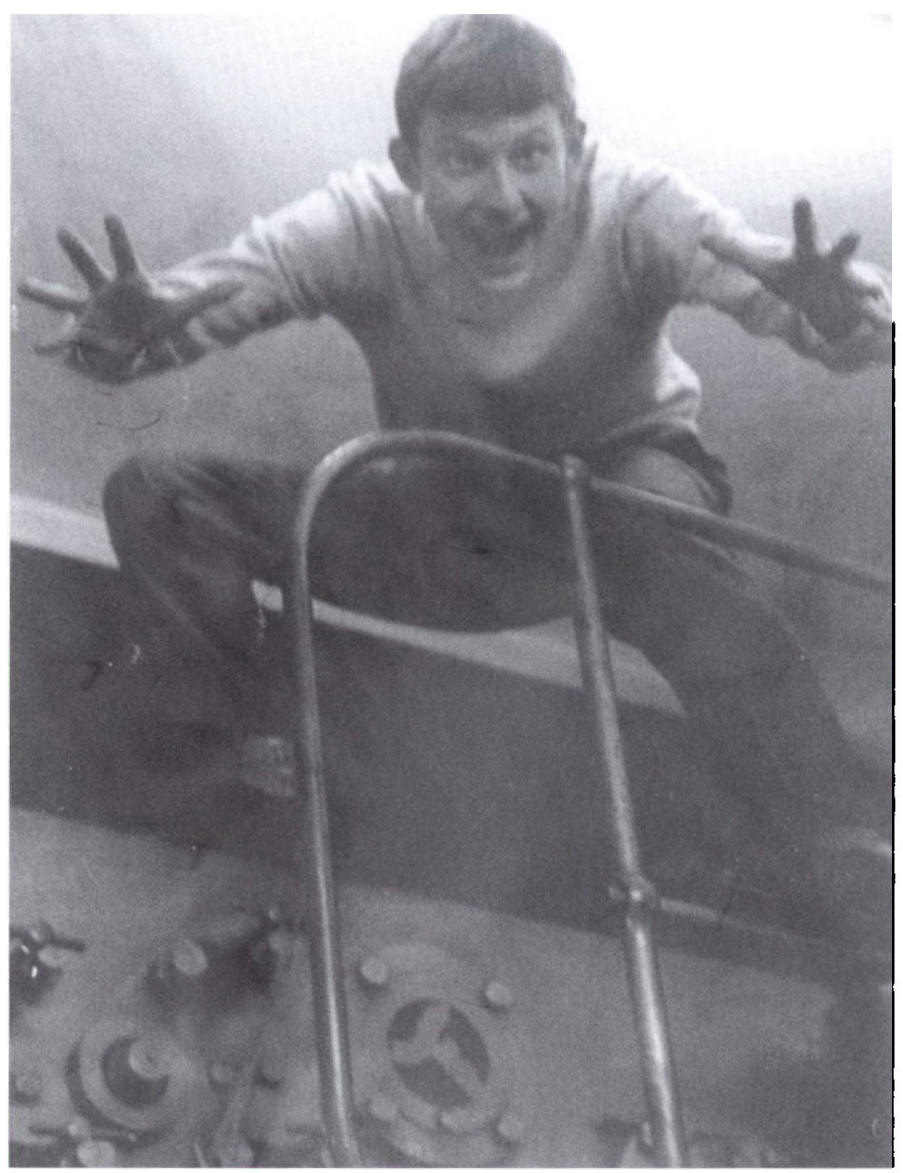

Flemming Nielsen på spring, stående på rotationspressen $i$ trykkeriet på Sønderjyden $i$ 1966. Foto: Torben Poulsen. I privateje.

lig højt op i rækkerne. Ved vintertide i Frihedshallen var det håndboldherrerne fra Vidar og Dybbøl, jeg fulgte. Indimellem var vi en lille koloni af lokale reportere og fotografer, der berettede om de lokale helte. I flæng kan jeg fra Vidars 3. divisionshold nævne Helge Høi, Viggo Poulsen og Hans J. Snerling. Fra Dybbøls mesterrækkehold Henning Jørgensen, Bent Mieritz og Kristian Skivild. Og nogle af profilerne på SB's serie 1-hold i fodbold var Ole Grünfeld, Egon Barsøe og Poul Hansen.

Også de højere rangerende hold i bl.a. Haderslev, Aabenraa, Vojens 
og Tønder blev fulgt nøje, men dem tog de sig af på lokalredaktionerne. Kampreferaterne fra Vojens blev af og til illustreret med fotos taget af fotograf Jørgen Kølle. Han var i 1960'erne på begynderstadiet som fotograf. Med årene blev han en slags »kongelig hoffotograf« for aviser og ugeblade med gode kontakter til kongehuset.

Ved særlige lejligheder dækkede jeg også sportsbegivenheder uden for Sønderborg. Søndag var altid min travleste dag. Ofte var der kampe både om dagen og aftenen, og alene dét at samle og redigere det vigtigste stof fra ind- og udland tog lang tid. Ikke sjældent var jeg først færdig ved 02-tiden, og så sov jeg på fire kontorstole, som jeg rykkede sammen. Mandag fra tidlig formiddag skulle jeg - i samarbejde med typograferne - "bryde sportssiderne om ", altså placere de enkelte artikler med overskrifter og fotos på en hensigtsmæssig måde på siderne.

Atletklubben (brydeklubben) Alsia var en klub, der virkelig blev regnet med i Danmark. I mine år på Sønderjyden overværede jeg et væld af stævner med deltagelse af lokale navne som Walter Kleemann, Svend Skrydstrup, Bent Samsøe, Allan Karring og brødrene Ola og Bent Aasand. Tilsammen repræsenterede de et væld af danske seniormesterskaber og landskampe. Svend Skrydstrup, den elegante og dygtige tekniske bryder, deltog året før min entré i Sønderborg i OL i Tokyo.

Jørgen Jørgensen var $\mathrm{i}$ tre perioder en særdeles markant formand for Alsia, og også i Dansk Atlet-Union beklædte han formandsposten. "Jønne", som alle kaldte ham, forsynede mig med et væld af solonyheder, bl.a. om "Alsia-Cup«, det store internationale brydearrangement, som jeg dækkede i flere år i træk i Sønderborg.

Selvom Sønderjylland ikke just var - eller er den mest dominerende landsdel på sportsfronten, har der altid været gode præstationer, både individuelt og for hold. Vojens Ishockey Klub så dagens lys i 1963, og samme efterår blev den indendørs bane taget i brug. Klubbens kampe blev fulgt tæt af Sonderjyden, og i 1969 kunne jeg berette, at klubben vandt bronze ved DM.

\section{Sympatiske Larsen to gange til OL - men ingen medaljer}

I Gerd Larsen, der repræsenterede Haderslev IF og Aabenraa IG, havde Sønderjylland en dygtig mellemdistanceløber. Også hans karriere 


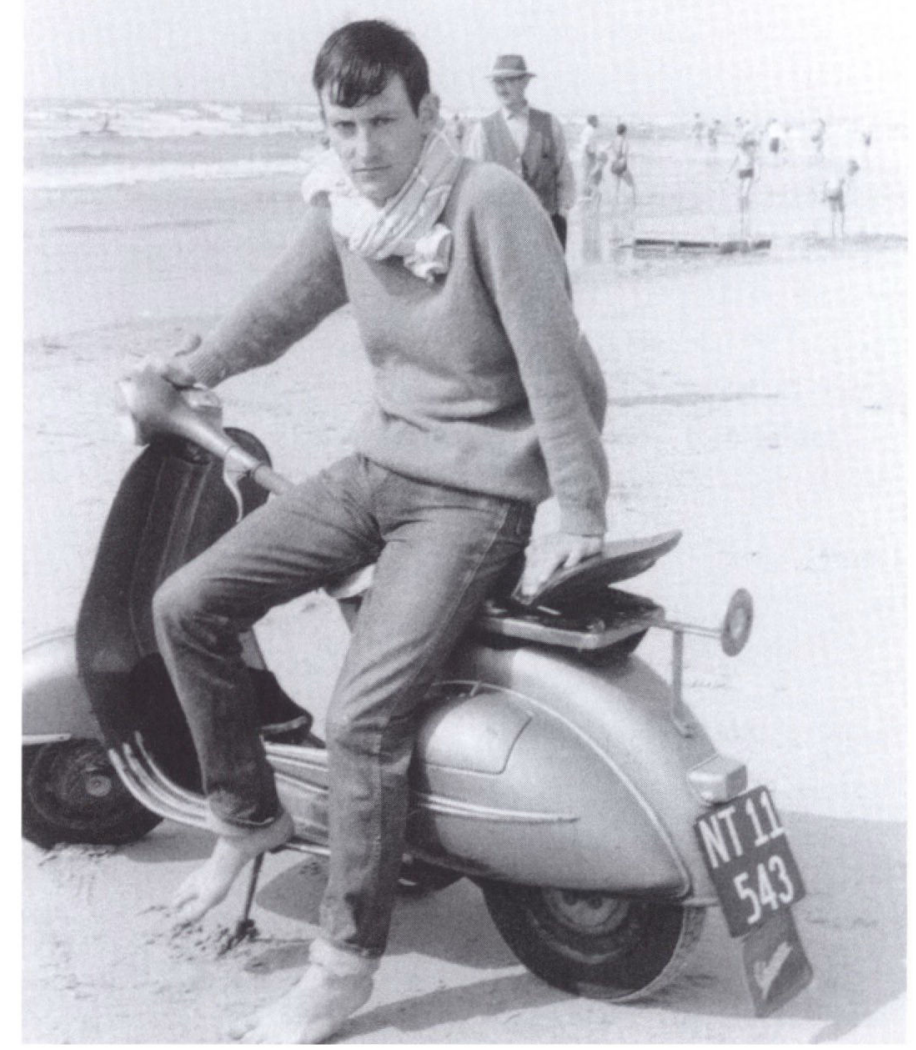

Den forste tid kom den unge journalistspire rundt på cykel eller med rutebil. Efter sin 18-års fødselsdag i 1966 anskaffede han sig en Vespa scooter. Det blev nu nemmere at komme omkring og dakke navnlig de mange sportsbegivenheder, som journalisteleven - nu med titel af "sportsredaktor" - havde som sit sarlige ansvarsomrade. Flemming Nielsen fotograferet på Lakolk Strand på Rømø i 1967. Foto i prizateje.

fulgte jeg på tæt hold. Gerd Larsen toppede i slutningen af 60'erne og begyndelsen af 70'erne. Han repræsenterede Danmark ved OL i Mexico i 1968 på 800 meter og ved OL i München i 1972 på 1500 meter. I september 1968 redigerede jeg Sønderjydens ekstra-udgave om OL i Mexico, hvor jeg interviewede Gerd Larsen. Han var 26 år og seminarieelev og glædede sig selvsagt til at komme til Mexico. Han trænede tidligt om morgenen og igen om eftermiddagen, og de ben, 
der ofte voldte ham problemer, havde det fint på dette tidspunkt. Men der blev ingen medaljer til den sympatiske sønderjyde, hverken i Mexico eller i München. I øvrigt mødte jeg Larsen på ny, da jeg var ansat ved DR.

Også bordtennis, tennis, sejlsport, atletik og bueskydning var blandt de sportsgrene, jeg ofte beskæftigede mig med som "sportsredaktør«, og efter min 18 års fødselsdag i 1966 fik jeg lidt lettere ved at komme rundt. Jeg tog kørekort til både motorcykel og bil, og efter et par år med en Vespa-scooter, tog jeg op til Voigt \& Rasmussen på Alsgade og købte mig en brugt Renault 4 L. Det betød bl.a., at jeg snildt kunne smutte på Nybøl-Banen, når der var motorløb med de lokale helte, bl.a. Erling Sjøholm.

Ligesom de "rigtige« sportsredaktører skulle også jeg have min egen klumme - og den fik navnet "Minge mener". Her gav jeg min mening til kende om regionale, nationale og internationale begivenheder og tiltag fra sportens verden.

I Johannes Heesch, der var sportsmedarbejder på Jydske Tidende i 70 'erne, havde jeg en rigtig god kollega. Vi fulgtes tit til bl.a. fodboldog håndboldkampe - og hvis én af os kom for sent eller ikke nåede frem, forsynede vi hinanden med de nødvendige oplysninger. Ganske vist var vi konkurrenter fra hver sin avis, men $i$ endnu højere grad var vi kolleger. Johannes Heesch sagde farvel til pressen efter en lang årrække som JydskeVestkystens dygtige udgaveredaktør i Sønderborg.

\section{"Druknede i hash-rus«}

Heldigvis var det ikke kun sportsstoffet, jeg kom til at beskæftige mig med på Sønderjyden. Før jeg forlod avisen ved udgangen af november 1970, havde jeg været "hele vejen rundt«. Jeg skrev om kommunalstof, landbrug, militærstof, arbejdsmarkedsstof, navnestof, kriminalstof og meget, meget mere. Under utallige retsmøder, hvor jeg mødte op som referent, fik jeg et godt indblik i samfundets skyggesider. Det var især kriminalsager, avisen dækkede, og jeg mødte mange skæbner, der skulle have gjort regnskabet op efter en lovovertrædelse.

Der skete voldsomme ting på kriminalområdet i mine år på Sønderjyden. Antik-Andersen blev myrdet - og det samme blev vores gode kollega på Dybbøl-Posten, Marie Engmark. Drabet på hende fandt sted fredag den 11. november 1966 tidligt om morgenen ved Dybbøl- 
gade i Sønderborg, da hun var på hjem hjem fra arbejde. Om aftenen havde 23-årige Marie Engmark dækket et vælgermøde i Vester Sottrup.

Ikke mindst som ung journalist var det noget ganske særligt at kunne præsentere en rigtig forside-basker. Sådan én kunne jeg glæde mig over mandag den 16 . november 1970 , selvom det var på en tragisk baggrund. Over fire spalter berettede Sønderjyden: "Druknede i hash-rus, tyskerne ønskede ikke hjælp fra dansk side«. Bag overskriften gemte sig følgende tragedie: En 20-årig kok fra Flensborg, forhyret på fjordbåden "Gorch Fock «, blev meldt savnet på skibet lørdag ved 14-tiden. Han var sidst set en time før. Det menes, at kokken er faldet - eller sprunget - i Flensborg Fjord mellem bøjerne seks og syv. Vidner fortalte, at manden var blevet dårlig efter at have røget hash. Han skal have slået omkring sig, men det var lykkedes for besætningen af berolige ham. Søværnets Operative Kommando i Århus tilbød at assistere ved eftersøgningen af kokken, men det ville de tyske myndigheder ikke tage imod.

Heldigvis var ikke alle avisartikler om fjordbådene (læs: "Spritbådene«) så tragiske. Disse både pløjede bølgerne på Flensborg Fjord i årtier, bl.a. fra Sønderborg, Gråsten og Kollund. De gav anledning til mange nyheder, når de blev handlet eller havde uheld, når der blev smuglet - eller når folk skejede ud i Sønderborgs natteliv efter at have lagt bunden om bord på Hansaline, Margrethe og Feodora, og hvad skibene ellers hed.

\section{Piberygende gentlemen of the press}

Vi journalister fra Sønderborg holdt os ikke tilbage. Ofte indledte vi en bytur på en spritbåd med dejlig mad og et ikke ubeskedent kvantum af de våde varer - altsammen til toldfrie priser. Ikke sjældent var journalister fra tre-fire af byens aviser med, og efter nogle gemytlige timer til søs fortsatte det muntre samvær på Slotsrestauranten, hvor vi svingede pigerne - eller på Misses Kro. Her trakterede Misse herself klaveret, alt imens vi piberygende "gentlemen of the press « - iført vore tykke islandske sweatre - drillede hinanden med, hvilke nyheder vi havde snydt de andre for. Når tørsten bankede på, drak vi Gammel Carlsberg og Rod Tuborg. Sulten fik heller ikke lov til at plage os længe ad gangen; så blev der bestilt »Solæg«.

Selvom vi ind imellem vaklede hjem ud på de små timer, mødte 
vi - næsten - altid på arbejde til tiden. "Ka' du gå på druk og kæresteri en hverdagsaften, ka' du sgu også passe dit arbejde«, tordnede Sigfred Jespersen - altid ledsaget af et smittende grin. Han og fru Anna var ikke sjældent med om bord på de lystige ture til Langballig.

Som lokaljournalist kom man i 60'erne ikke udenom at producere en hel del »rugbrødsjournalistik «: Pligtstoffet, de brækkede ben, tyveri af en kasse øl, nye fortovsfliser i Havbogade osv. Men heldigvis var der også lyspunkter, hvor man kunne glæde sig over, at man havde valgt netop journalistikken. Sådan havde jeg det, da jeg traf forfatteren Jacob Bech Nygaard ("Guds blinde øje ") til en foredragsaften i Selskabelig- og Ungdomsforening for Hostrup Sogn i Jejsing ved Tønder. Bech Nygaard, der døde i 1988, var den første forfatter, jeg interviewede. Arrangementet var ét blandt mange i min ungdom, hvor man refererede et foredrag, noget der sker yderst sjældent i vore dage.

\section{Synnejysk}

Siden barndommen har sønderjysk altid været mit foretrukne »modersmål«. Bevares, sønderjysk ER jo en dialekt og ikke et sprog, men af de tungemål, jeg behersker (sønderjysk, dansk, tysk og engelsk), taler jeg helst sønderjysk. Dels fordi det er smukt, dels fordi jeg er flasket op med det - og naturligvis fordi det er det, man taler i min hjemstavn.

I mit arbejde som journalist har jeg bevidst og helt målrettet forsøgt at være med til at fremme brugen af sønderjysk. Som avisjournalist har jeg ikke sjældent taget temaet op. Og som radiojournalist har jeg altid opfordret folk til at bruge deres dialekt, hvis det faldt mest naturligt for dem.

Jeg har ikke noget tilovers for dem, der nedgør dialekter. Heller ikke for dem, der gør, hvad de kan for at deres børn udelukkende skal tale rigsdansk - og senere hen lære fremmedsprog. I mit univers er man sej, når man "snakke' æ sproch“. F.eks. kunne jeg ikke drømme om at indlede en samtale på rigsdansk, når jeg taler med et menneske, som jeg ved taler sønderjysk. Det kan Kresten Philipsen, Jørgen Mads Clausen, Hans Heinrich Hansen, Asger Reher, Ole Olsen, René Rasmussen fra denne årbogs redaktion og mange andre fra området bevidne - og det kunne også nu afdøde H.P.Clausen. At jeg så i min tid som radiojournalist slog over i rigsdansk, når der blev tændt for mikrofonen, er en anden ting. 


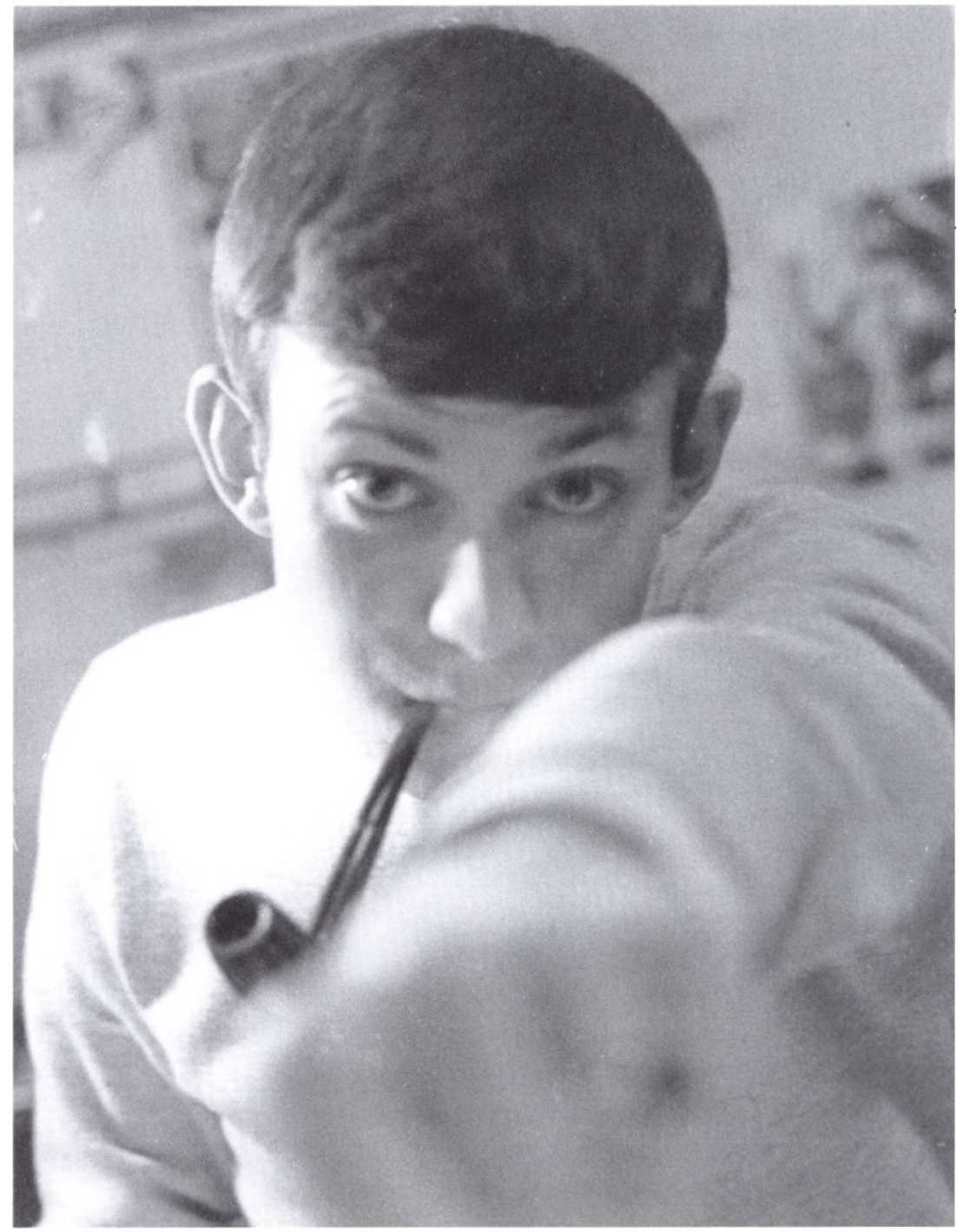

Hardtsläende journalistelev med pibe. Nast efter skrivemaskinen horte pibe og islandsk sweater med til standardudrustningen for en journalist $i$ slutningen af 1960'erne. Foto i privateje.

Jeg har mødt mennesker, der mener, at radiojournalister med en sønderjysk baggrund bør bruge dialekten i radioen. Dem er jeg uenig med. Radio Syds sendeområde går helt op til Ølgod og Sønder 
Omme - og folk i de egne skal ikke tvangsindlægges til at høre, at "Hans Petsen hæ fåt stjål tyve pa' ynnebaus ue å e tøjsnoe' i æ kalgå«. At man så i særlige temaudsendelser kunne beskæftige sig med alle dialekter i sendeområdet, er en anden ting. Dialekten skal ikke hindre ikke-sønderjyder $\mathrm{i}$ at forstå budskabet - men modsat skal den heller ikke forbigåes i elektroniske medier.

Jeg ved godt, at nogle mennesker finder, at dialekter kun er for »almuen« (jævne mennesker på landet). I så fald er jeg almue. De samme mennesker bliver forlegne, når man beder dem tale den dialekt, de har lært fra barnsben. Det har jeg aldrig forstået. Hvordan kan man blive flov over at bruge det tungemål, mennesker har kommunikeret på i mange generationer i det nuværende grænseland? Og hvorfor drives der dialektforskning på institutter i Århus og København - og kun i mindre omfang i Sønderjylland?

Jeg kunne ønske mig, at man også fra mere officiel side forholdt sig positivt til brugen af dialekter. Det virker nærmest grinagtigt, når man i en byrådsdebat i Sønderjylland hører en person forsøge sig på rigsdansk, selvom enhver ved, at han/hun kun snakker sønderjysk i hverdagen.

\section{En ung lokalredaktør}

Som bekendt er journalistuddannelsen i vore dage tilrettelagt helt anderledes, end den var i min tid. I dag er uddannelsen meget mere teoretisk - og det kan være næsten umuligt blot at blive optaget på grund af de mange ansøgninger. Er man så heldig at komme ind på uddannelsen, begynder og slutter man på uddannelsesstedet efter at have været i praktik. Langt de fleste af dem, der arbejder som journalister i dag, er uddannet enten på Danmarks Journalisthøjskole, Syddansk Universitet eller Roskilde Universitet.

Der er sikkert både fordele og ulemper forbundet med den gamle og den nye uddannelse, men for mig var det fint at blive smidt ud $i$ den direkte udøvelse af faget - suppleret med fem måneders teori $\mathbf{i}$ Århus. I dag kan jeg undre mig over den tillid, Sønderjyden viste os elever. Da avisens redaktør i Haderslev havde forfald i nogle uger, stod en anden elev, Torben Poulsen og jeg for dækningen af lokalstoffet $\mathrm{i}$ området med redaktionen i Nørregade som base. $\mathrm{Og}$ da en ny lokalredaktør i Tønder blev forsinket nogle uger, måtte jeg - ene 
mand - fylde den daglige Tønder-side med stof. Vel at mærke endnu før jeg havde været journalistelev i et halvt år.

Af avisens kolofon fremgik, at Flemming Nielsen var konstitueret som lokalredaktør på redaktionen, Vestergade $76 \mathrm{i}$ Tønder. Man undlod dog at fortælle læserne, at jeg kun var 18 år og havde meget at lære endnu. Men jeg skrev skam med stor begejstring om, at en hotelforpagter var varetægtsfængslet for trusler og vold mod tjenestemand i funktion, at der skulle oprettes en menighedsbørnehave i Møgeltønder - og at mus og muldvarpe var godt i gang med at ødelægge Rømø-dæmningen.

Min læretid i Sønderborg var i mange henseender en god, glad og sorgløs tid. Værelset på Dybbøl Banke blev erstattet af et hummer på Ahlmannsvej, der var så lille, at der - ud over mig - dårligt nok ville have været plads til et marsvin i bur. Så var jeg mere begejstret for at bo på "Herrekollegiet « på Søndre Landevej. Min sidste adresse fik jeg i et kælderværelse på Møllegade.

\section{I trøjen, i hovedstaden og i Vendsyssel}

Som rekrut på Flyvestation Skrydstrup kom jeg ind i helt nye omgivelser på en ti-mands stue. Herfra gik det videre til en radarstation i Nordsjælland, hvor jeg blev uddannet til varslingsoperator. Det var i den kolde krigs dage, og efter endt uddannelse blev jeg udstationeret på en radarstation uden for København. Mit arbejde med at følge og varsle - den civile og militære flytrafik var særdeles spændende, og jeg hører til blandt dem, der ikke har meget negativt at sige om min soldatertid. Da der ikke var flere datoer at klippe af på mit centimetermål, blev "Menig Nielsen « hjemsendt. Sønderjyden havde på forhånd sagt, at jeg var velkommen tilbage - og det takkede jeg ja til. Men 1. december 1970 sagde jeg "mojn« til Als og Sundeved og satte kurs mod hovedstaden. Derovre ventede en stilling som reporter på B.T. Det var ganske udviklende at stifte bekendtskab med journalistikken på en helt ny måde - og det var en oplevelse at være på tomandshånd med mange kendte ansigter, som man ellers kun kendte fra $\mathrm{TV}$, radio og andre medier. Det var også sundt at lære at håndtere den indflydelse, man uvilkårligt får, når man arbejder på en avis, der læses af tusindvis af mennesker hver dag. Men mine spændende og lærerige år som københavnerjournalist er en anden historie.

Efter tre år skulle der igen ske noget nyt, og bladhuset i Kristen 
Bernikowsgade i København blev fra 1. december 1973 skiftet ud med Vendsyssel Tidendes bladhus på Skolevej i Skagen - tæt på hovedstrøget Sct. Laurentii Vej. Venstreavisen havde ansat mig som lokalredaktør, og Lykke og jeg - og vores lille søn, Kasper - kunne glæde os over, at en 2-værelses lejlighed i Rødovre nu var erstattet af en stor villa med redaktion i stueetagen $i$ en af landets dejligste byer.

Perioden som leder af Vendsyssel Tidendes nordlige forpost modnede mig yderligere som journalist. Jeg lærte en masse om kunst og kultur, turisme, fiskeri og meget, meget mere. Bl.a. det berømte Skagens Museum kastede mange nyheder af sig. Desuden fandt jeg ud af, at det godt kunne give panderynker og grå hår, når jeg i årevis skulle "slås" med en borgmester, der oplevede en jordskredssejr ved et kommunalvalg. Hans magt $\mathrm{i}$ kommunen var på det nærmeste uindskrænket - og det irriterede ham som venstremand og aktionær i avisen, at jeg insisterede på, at avisen var mit - og ikke hans ansvarsområde. Når borgmesteren var sur og nægtede at udtale sig, stod andre politikere nærmest i kø for at orientere mig, så det var kun sig selv, han ramte.

Ud over mig var der ansat en journalist og en kontorassistent på redaktionen, og med så få personer var det anstrengende at arbejde på en avis, der udkom hver dag ugen igennem. Derfor takkede jeg ja, da Danmarks Radio i Åbenrå - Radio Syd - i 1983 tilbød mig et vikariat. Stillingen blev senere udskiftet med en fast stilling.

\section{Radio Syd}

Den Nielsen'ske familie var med årene blevet suppleret med yderligere to børn, Stine og Kristian, samt en hund og en kat, og den 14. november 1983 kørte vi ud af Skagen i en overfyldt Volvo Amazon med kurs mod Broager. Dagen efter tog jeg hul på et nyt arbejdsliv i Danmarks Radio, der skulle komme til at strække sig over lige knap 25 år. Radio Syd, H.P.Hanssens Gade 11 i Aabenraa, er en populær institution i grænselandet - og den ældste af de ni regionalradioer. Netop her i 2010 kunne DR's afdeling i Aabenraa fejre 50 års jubilæum. "Den syd- og sønderjyske regionalradio « har haft adskillige navne gennem årene, men $\mathrm{i}$ min - og mange andre midaldrende og æeldre sønderjyders - bevidsthed vil radioen også i fremtiden være »Radio Syd «.

Det var den kendte og folkekære Frode Kristoffersen, der blev min 
første chef. Ham har jeg bevaret kontakten til også efter mit farvel til radioen. Frode kræver ingen nærmere præsentation. Han er lige så tæt knyttet til landsdelen som jeg selv - og han elsker at genopfriske gamle, fælles minder: »Nieeeelsen - ka' då haus dengang u'e i Synneborre - æ tro'e det vå ne'e å Misses Kro« ... Og det kan jeg da heldigvis som regel - altså huske, hvad det er, Frode tænker på.

I Frodes cheftid tog DR-møder i København og andre steder en stor del af hans tid og opmærksomhed. Det er vel aldrig helt lykkedes for DR at få kvalt de værste, bureaukratiske arbejdsgange og systemer og det ramte bl.a. Frode. Så blev de daglige gøremål og beslutninger overladt til hans souschef, Henry Johansen. Han havde et hjerte af guld - og hans udgangspunkt var altid: »Du skal se, det finder vi nok ud af«.

Rent håndværksmæssigt var det lidt af en kold douche for mig at skifte fra avis- til radiojournalist. Jeg var 35 år, da jeg første gang blev sendt "i marken « med en stor og tung Nagra-spolebåndoptager. Indføringen i teknikken - også i studierne - var nødtørftig, og jeg har aldrig forsøgt at give indtryk af, at jeg har et intimt forhold til teknik. Det kan kollegaer som Erik Ohlsen, Inger Bach, Erik Larsen og Torben Ølholm skrive under på. Det var nogle af de journalister, jeg arbejdede sammen med i de forste år, og som var ansat, da jeg gjorde min entré. Det samme var blandt andre Jørgen Møller, Jens Kodal, Carlo Hvidkilde, Bjarne Tybjerg, Jan Elton, Saren Vesterby, Peter Bjerg Poulsen, Sigfred Jespersen, Jørgen Kreutzmann, Ann Strandmark, Johannes Reimer, Helle Lundberg, Kaj Højgaard, Hans Lyhne Møller og Fred Jacobsen - for blot at nævne nogle af de navne, som vil lyde velkendt $i$ bevidstheden hos mange radiolyttere, der har passeret deres pureste ungdom.

En håndfuld af dem er for øvrigt fortsat ansat $\mathrm{i} \mathrm{DR}$, mens Inger Bach's karriere har haft en næsten stejl kurve. Hun var - og er garanteret stadig - en fremragende programmedarbejder, men hendes funktion som direktør for DR Danmark levner ingen tid til, at hun producerer programmer som »Spørg om sundhed «, »To generationer spiller ud« eller andre "Aabenraa-succeser«.

Gennem årene har jeg haft et stort antal dygtige og gode kollegaer/ arbejdskammerater - ingen nævnt, ingen glemt - bortset fra dem, der var med til at åbne radiofoniens forunderlige verden for mig i begyndelsen. Der gik dog ikke så voldsom lang tid, før jeg kom efter dét med at lave radio. I den første halve snes år var jeg allroundjournalist. Jeg skrev og læste nyheder op, var studievært, reporter, sportsreporter osv. 


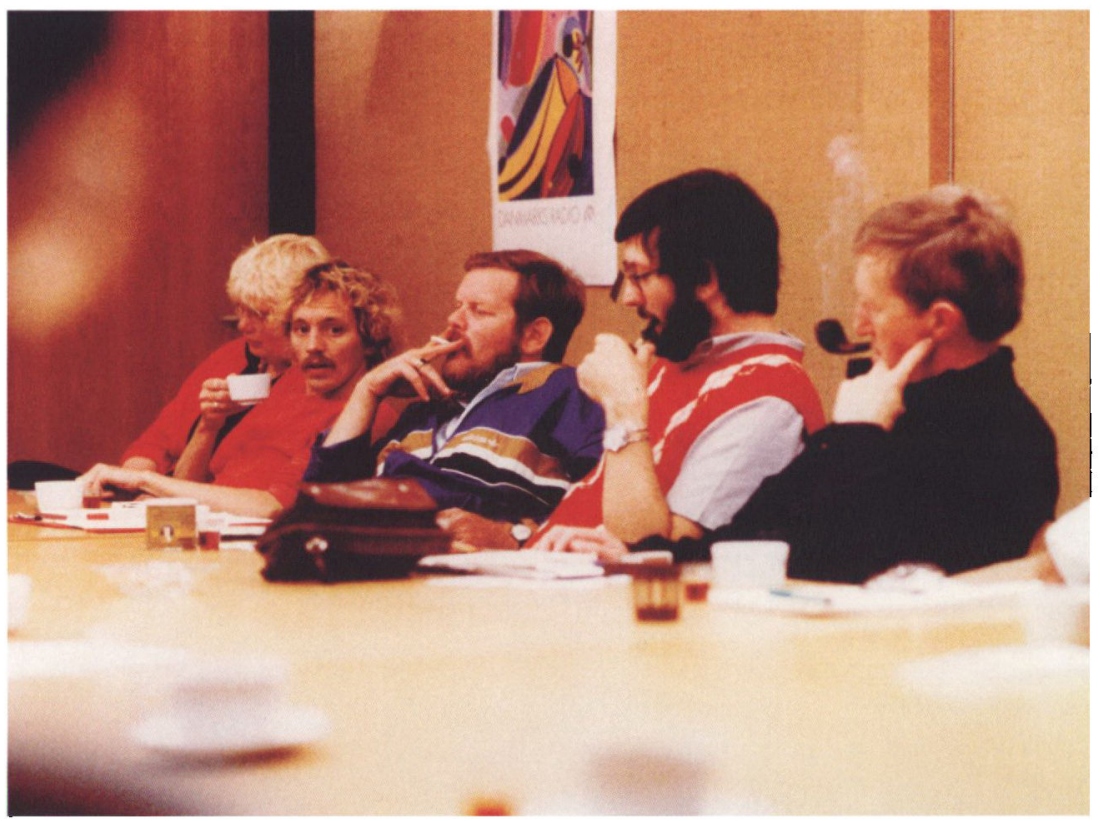

Redaktionsmøde på Radio Syd $i$ 1980'erne - med tobak og Gammel Dansk på bordet. Det var en anden tid. Journalisterne er fra venstre Helle Lundberg (nu kommunikationsmedarbejder hos Syd- og Sonderjyllands Politi), Kaj Højgaard (nu TV Syd), Erik Ohlsen, Flemming Nielsen med langt hår og skæg - og yderst til hojre Bjarne Tybjerg. Foto i privateje.

Når jeg i en alder af 62 år kigger i bakspejlet, vil jeg ikke lægge skjul på, at jeg som radiojournalist kom på den helt rette hylde. Via de forskellige funktioner var der stor variation $\mathrm{i}$ arbejdet. Jeg havde stor fornøjelse af at tage ud med båndoptageren. Ikke sjældent kørte jeg "ud i det blå«, og var jeg heldig, fik jeg mit første indslag på bånd $\mathrm{i}$ Rødding, nummer to $\mathrm{i}$ Skodborg, nummer tre i Bramming og nummer fire i Grimstrup. Ofte var det mere oplevelse, oplivelse og hverdagsmæssige ting end decideret journalistik, der kom ud af disse ture. Jeg husker stadig mit uanmeldte besøg i en børnehave $\mathrm{i}$ Rødding en december, hvor en bette knægt sang sin helt egen version af "Nu' det jul igen«. I det hele taget var jeg glad for at få børn til at fortælle $\mathrm{i}$ radioen - gerne på dialekt. $\mathrm{Og}$ når en bette pige tonede ud gennem højttalerne en morgen klokken 08.42 med sin historie om katten derhjemme, "der havde fået hvalpe - nå'e neeeeej, killing- 


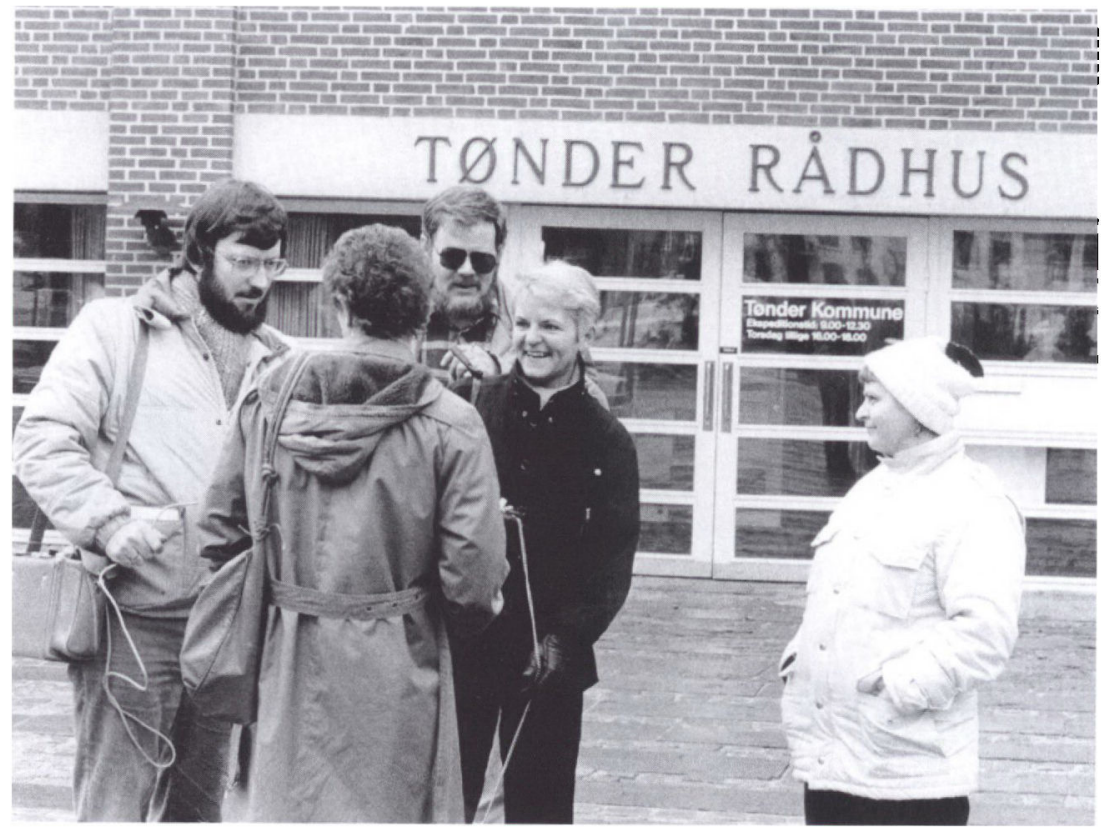

Aprilsnar! Flemming Nielsen, til venstre med den uundværlige Nagra spolebåndoptager, og Erik Ohlsen interviewer en lille gruppe kvinder foran Tonder Rådhus $i$ forbindelse med en aprilspøg $i$ Radio Syd sidst $i$ 1980'erne. Foto: Jargen Kolle. I privateje.

er ...« - ja, så var dagen reddet i mangt et hjem i Syd- og Sønderjylland.

\section{Uhøjtidelighed og grineflip}

Som vært, bl.a. om morgenen, var det et ekstra plus også at have indflydelse på, hvad lytterne skulle høre af musik, og jeg gjorde, hvad jeg kunne for også at tilgodese det regionale musikliv med navne som Helge Engelbrecht, Vos, Sand på gulvet, Alice \& Rita, Vestre Jazzværk og Trine Gadeberg.

Det var en stor fornøjelse at arbejde for så mange tilfredse lyttere. Uanset hvor meget vi dummede os, bar lytterne over med os - og i det meste af min tid på Radio Syd var vi den mest aflyttede regionalradio. Altså hvis vi lige ser bort fra Bornholms Radio, der jo dækker et lille område med et beskedent befolkningstal. Vores succes hang vel 
sammen med, at vore nyheder var relevante og troværdige - at vore længerevarende udsendelser var spændende og vedkommende, og at tonen i morgenprogrammet ofte var uhøjtidelig, men ikke for pjattet eller kammeratlig. F.eks. Erik Ohlsen kunne få humørbarometeret op med adskillige grader, når han fortalte en vits - eller når han fik et grineflip ind imellem. Det er slet ikke af vejen i radioen. Latter har det med at smitte - også fra radiovært til lytter. Fred Jacobsen, der nu er næstformand i Dansk Journalistforbund, kan også snakke med om, at det kan være næsten umuligt at holde op med at grine foran mikrofonen, når man først er kommet i gang. Jeg har selv flere gange været involveret $\mathrm{i}$ at holde lytterne for "aprilsnar", og det kunne virkelig få snakken i gang på arbejdspladserne og i hjemmene.

Min interesse for alt, hvad der har med landsdelen at gøre, bl.a. det historiske og dialekten, fik i sandhed lov til at smitte af på, hvad jeg lavede til radioen. Det skete bl.a. i det program, der hed "Grænselandsportræt", og som Radio Syd sendte én gang ugentligt med mig som vært et par år. Nogle af de interviews, jeg endnu husker, var med personligheder som Henry Buhl, Silke Hinrichsen, Hans Ole Hansen, Johan Peter Noack, Christa Hansen, Rolf Lehfeldt, Sophie B. Jensen og Torben Rechendorff.

Engang præsenterede jeg tidligere købmand Nis Branderup fra Aabenraa. Anledningen var, at $Æ$ Amatøer i Sydslesvig havde udgivet hans bog, "Hans Lassen haj en bu'ndgård«. Branderup elskede at skrive - og læse - små historier på sønderjysk. Han fortalte i "Grænselandsportræt « bl.a. om de skel, der var før og under 2. Verdenskrig mellem sønderjyder og hjemmetyskere: "Som børn havde vi ingen problemer indbyrdes. Vi legede godt sammen - og nogle af dem meldte sig til tysk krigstjeneste, da de fik alderen til det. Mange af mine bedste venner blandt hjemmetyskerne ligger nu begravet $i$ Rusland «, fortalte Nis Branderup. Han hørte selv til den danske flertalsbefolkning.

Også Petra Seehaus fik sagt et par »sandheder « i »Grænselandsportræt « om det at være en aktiv del af det danske mindretal i Sydslesvig. Da jeg interviewede hende, underviste hun i keramik på Jaruplund Højskole, men hun kom oprindeligt fra Koblenz ved Rhinen. Allerede som spæd havnede hun i Sydslesvig, som familien flyttede til: »Vi skal ikke være så forbandet danskfikserede. Nogle gange er der for meget rødt-hvidt. Selvom Dannebrog er et hyggeligt flag. Men 
vi skal tage det som nogle gode farver på et billede til et grønt landskab med en bondegård ", sagde Petra Seehaus.

I samme program - et par uger efter Petra Seehaus - kunne jeg præsentere den tidligere daglige leder af Frøslevlejrens Museum, Hans S. Bruun fra Padborg. Som modstandsmand i Ribe i 40'erne blev han anholdt af Gestapo og havnede i Vestre Fængsel i København. Bruun reddede livet takket være den generalstrejke, der brød ud, men senere blev han udsat for mange prøvelser i bl.a. kz-lejrene i Neuengamme og Svesing ved Husum. Hans S. Bruun nedfældede nogle af sine oplevelser og tanker i bogen "På dødsmarch gennem Hitlers Tyskland«.

\section{»Heja hop - hare hop«}

Før jeg blev grænselandsmedarbejder 1. november 1993, havde jeg bl.a. produceret en hel del andre "lange" programmer på enten 2025 minutter eller en lille times tid. Ét af disse programmer optog jeg under en klapjagt på Broagerland i begyndelsen af 1989. Jeg var med fra start til slut med min tunge båndoptager over skulderen - op og ned ad agrene, til jagtfrokost i vaskerummet hos Birthe og Børge Ohrt i Dynt - og til vildtparade, ligeledes i Dynt. Jeg havde givet programmet titlen "Heja hop - hare hop«, og det gav vist lytterne en meget god fornemmelse af, hvad der foregår under en klapjagt. Her har samværet, frokosten og de gode historier, som jægerne overgår hinanden med, ligeså høj prioritet som selve jagten. Og så var der rigtig god lyd fra geværer, der bragede, jægere, der råbte til hinanden - og en syngende borgmester fra Billund, Erik Tychsen. Han stammede selv fra Broagerland.

I 1984, cirka et år efter min radio-debut, fik jeg lejlighed til at sætte fokus på nogle glemte - og mindre kendte - seværdigheder i landsdelen. Jeg husker endnu, at H.E.Sørensen, Skærbæk, og jeg vandrede op og ned langs Alssund på Sundeved-siden. Her udpegede han og fortalte historien om nogle gamle bøgetræer, hvor man stadig - 120 år senere - kunne se, hvad de tyske soldater havde snittet $\mathrm{i}$ træerne før overgangen til Als i 1864. Det var hjerter, datoer, navne og den slags. En anden medvirkende var i øvrigt den kendte højskolelærer Richard Andersen, Askov.

Og før jeg tager hul på funktionen som grænselandsmedarbejder, vil jeg ikke undlade at nævne min samtale i 1986 med den dengang 


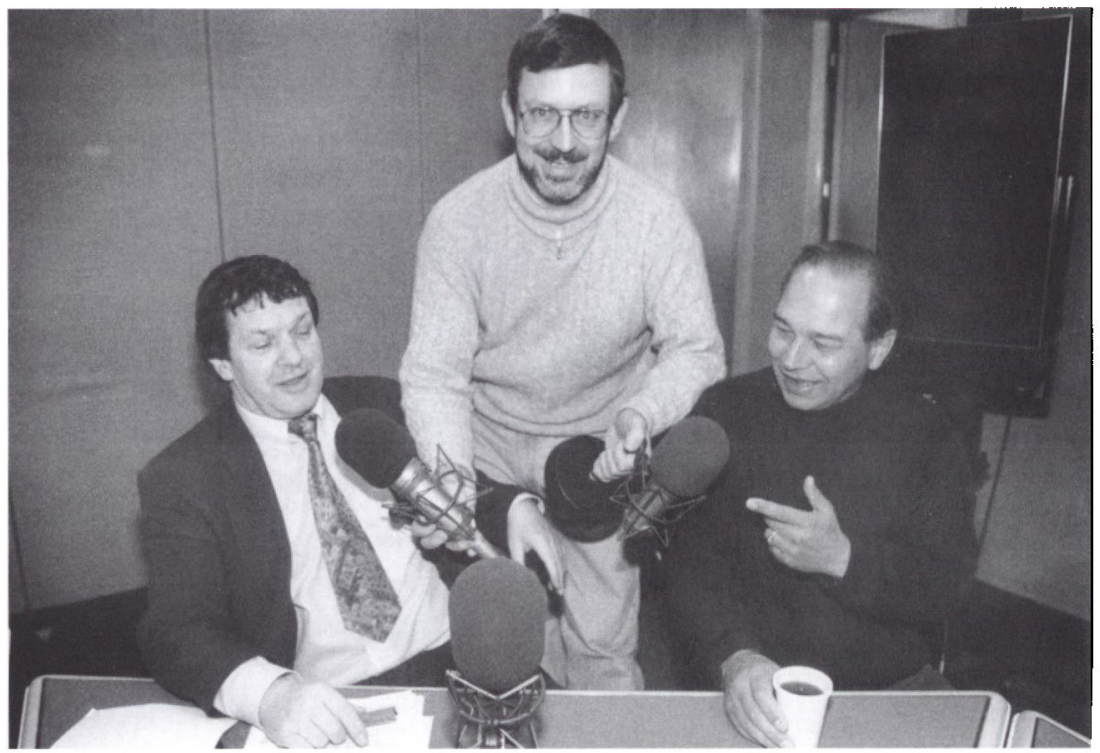

"Grænseland Europa" var $i$ en årrække en populær debatudsendelse $i$ Danmarks Radios Program $1 \mathrm{og}$ Radio Syd. Succesen skyldtes de to debattorer, til venstre chefredaktor for det tyske mindretals dagblad Der Nordschleswiger, Siegfried Matlok, og til højre højskoleforstander for Jaruplund Højskole $i$ Sydslesvig, Dieter Küssner. Foto: Karin Riggelsen. I privateje.

96-årige, tidligere kaptajn i rederiet J. Lauritzen, Christian F. Warming fra Alnor ved Gråsten. Han fortalte med stor indleven, godt hjulpet på vej af en fin hukommelse, bl.a. om sine oplevelser på de gamle sejlskibe - og om sin deltagelse i 1. Verdenskrig.

\section{Grænselandsmedarbejder}

Efter præcis ti års ansættelse i DR blev jeg den tredje grænselandsmedarbejder på Radio Syd efter Sigfred Jespersen og Jørn Buch. Stillingen var ikke opslået, men blev - som man siger - »besat internt «. Det var den daværende programchef, Elsebeth Sarauw, der foreslog, at jeg overtog funktionen - og det gjorde jeg med glæde.

Når man er født og opvokset $\mathrm{i}$ grænselandet med rødder på begge sider af grænsen, som jeg har (de fleste dog nord for grænsen), og når man er optaget af områdets historie og pulsslag, kunne jeg ikke forestille mig et bedre job end grænselandsmedarbejderens. Når jeg 
holder det af mine foredrag, jeg kalder »Journalist i 43 år - et eventyrligt liv«, så ligger eventyret ikke mindst gemt i mine 15 år som "Grenzlandredakteur", som Der Nordschleswiger ofte har kaldt mig.

Det har givet mig et par panderynker at skulle skrive om netop denne periode $\mathrm{i}$ mit arbejdsliv, for hvor begynder og hvor slutter jeg? Jeg har arbejdet med stoffet nyhedsmæssigt til både Radio Syd, Radioavisen, P1 og Radio Syds hjemmeside. Jeg har lavet et stort antal af programmet "Grænseland «, jeg har produceret debatudsendelsen "Grænseland Europa « i lige knap ni år med Dieter Küssner og Siegfried Matlok til landsprogrammet - og i syv år var jeg vært på »To generationer «, der ikke kun havde deltagere fra Sønderjylland, men fra hele sendeområdet fra Nymindegab, Ølgod og Sønder Omme i nord til Kielerkanalen og Ejderen i syd. I et års tid var jeg også vært på debatprogrammet med tre unge fra grænselandet, "Ipsen, la Cour \& Kleinschmidt«. Jeg har som grænselandsmedarbejder lavet radio med rigtig mange interessante mennesker, men kan af pladshensyn kun fortælle om få af dem.

\section{Mure omkring enklaver}

Drivkraften i min funktion som grænselandsmedarbejder har altid været at give lytterne et så alsidigt og relevant billede som muligt af grænselandet inklusive historie og mindretal - altså at føre lytterne så tæt på virkeligheden som muligt. Når man ikke selv er en aktiv del af det nationale eller politiske arbejde, kan det være vanskeligt at huske, hvad det nu lige er, BDN og SP står for - og hvad de tilbyder af aktiviteter i SSF og SSV. Helt bevidst har jeg ikke lavet radio for mindretallene - men om dem. Ved at lade mindretallenes repræsentanter komme til orde fik lytterne indblik i hverdagen hos hjemmetyskere og danske sydslesvigere. Jeg forsøgte at stille spørgsmål ved de mange paradokser, grænselandet også er fyldt med. Hvorfor snakker I så meget tysk i det danske mindretal - og hvorfor snakker I så lidt tysk - og mere sønderjysk - i det tyske mindretal? Hvorfor kan I ikke finde ud af at samarbejde på en mere hensigtsmæssig måde i Sydslesvig - hvorfor bygger I mure op omkring jeres små enklaver i stedet for at trække på samme hammel - og hvorfor er det - I jeres optik - i reglen »de andres skyld «? Listen over relevante spørgsmål er lang. 
Når jeg indimellem har spurgt mig selv, om det var ulejligheden værd at give mindretallene så stor bevågenhed, er det arbejdet på græsrodsniveau, der har leveret de positive svar. At mennesker vælger at leve en alternativ tilværelse kulturelt og til dels sprogligt, har krav på opmærksomhed. At mennesker siger, at de ikke kun har én, men flere identiteter og sprog, kan ikke bare ignoreres. Og det skal ikke komme de mange danske sydslesvigere til skade, at de få i toppen ikke kan/vil finde fodslag.

\section{Fårhus-mentalitet - og de andre}

Når meninger brydes, og mennesker udfordrer hinanden på holdninger, har jeg altid haft det bedst som journalist. Man kan heller ikke undgå at beskæftige sig med emner, der gør ondt på nogle. Når man er født tre år efter befrielsen, kan det være problematisk at sætte sig ind $i$, hvad der er rigtigt og forkert omkring det tyske mindretals rolle i krigen og besættelsen af Danmark. I 1995 fik jeg et tankevækkende indblik $i$, at vi mennesker ikke altid onsker at huske tingene, som de i virkeligheden var. Jeg deltog $i$ en festaften i soldaterforeningen "Der Kameradschaftsverband Nordschleswig «, et arrangement, der resulterede i et »Grænseland « på 25 minutter. Ikke én af de gamle soldater gav udtryk for, at der kunne stilles spørgsmålstegn ved deres deltagelse i 2 . Verdenskrig som tyske soldater. Ikke blot ét gram af selvransagelse. Tværtimod sagde en festdeltager: "Vi kæmpede rent, ridderligt og ordentligt. De forbrydelser, der skete under krigen, må tilskrives politikerne og ikke frontsoldaterne«. Kommentarer er vist overflodige.

Det tyske mindretal i Sønderjylland er efter min opfattelse veget tilbage for at tage et reelt selvopgør om perioden 1933-1945. Tværtimod har en del hjemmetyskere travlt med at vinde gehør i flertalsbefolkningen for det synspunkt, at mindretallet som helhed blev behandlet urimeligt af Danmark i forbindelse med retsopgøret. Den holdning deler jeg ikke - og det gør forresten mange i det tyske mindretal heller ikke. Den såkaldte Fårhus-mentalitet, der groede frem mellem de hjemmetyske fanger i Fårhuslejren, kan næsten give mig kuldegysninger. Tænk, at mennesker er i stand til at gøre hvide ting sorte - og omvendt. At være i stand til at fortrænge og fornægte et engagement og aktiviteter, der så entydigt var rettet mod det land, 
man var borgere $\mathrm{i}$ - og de mennesker, man levede side om side med er ikke til at forstå.

Min tilgang til denne del af grænselandets historie har dog aldrig på nogen måde påvirket min journalististiske dækning af hverdagen i det tyske mindretal. Jeg anerkender og støtter hjemmetyskernes ret til at drive egne institutioner som børnehaver og skoler - og det er flot, at der stadig er ildsjæle, som forsøger at holde liv i og udbygge tysk sprog, kultur og foreningsliv. Ikke mindst mange midaldrende og yngre mennesker $\mathrm{i}$ det tyske mindretal har en beundringsværdig tilgang til dét at tilhøre et mindretal. Og disse mennesker har i min formidling $\mathrm{i}$ radioen fyldt betydeligt mere end den langt mindre gruppe, der lever dele af deres mindretalsliv på en løgn.

\section{Personligheder i det tyske mindretal}

I det tyske mindretal har jeg mødt mange personligheder - kendte som ukendte - der var med til at gøre en forskel. Blandt dem Siegfried Matlok, Annelise Bucka, Hans Heinrich Hansen, Birgit Mørck, Stephan Kleinschmidt, Christa Hansen, Peter Iver Johannsen, Günter Weitling, Karin Sina, Gerhard Mammen, Gösta Toft, Heike Jacobsen, Hermann Heil, Jørgen Popp Petersen, Christa Toft, Uwe Jessen, Ilse Friis, Hinrich Jürgensen - ja, listen kunne blive meget længere. Hver på sin måde har disse mennesker - som oftest uden at skele til egen bekvemmelighed - slidt og slæbt for at fremme hjemmetyskernes sag. De har rendt politikere og myndigheder på dørene, de har argumenteret for »sagen « i medier og foreninger, de har forsøgt at opliste de mange fordele, der er forbundet med at give sin stemme til Slesvigsk Parti - osv. osv.

Lobbyisten over dem alle er Siegfried Matlok, Der Nordschleswigers chefredaktør. Hans force er hans store netværk - og hans manglende evne til at stå $\mathrm{i}$ anden eller tredje række. Siggi har det bedst in der ersten Reihe - og herfra har han været brobygger mellem dansk og tysk. Dels som chefredaktør, dels som sekretariatsleder i København, hvor han var i øjenhøjde med politikere, som andre i grænselandet mest kendte fra aviserne. Ikke mindst når vi producerede »Grænseland Europa«, lærte jeg at sætte pris på Matloks store viden om stort og småt i Europa. Internt i mindretallet er han ikke uomstridt. Når man i så mange år har snuden så langt fremme, er der måske andre, 


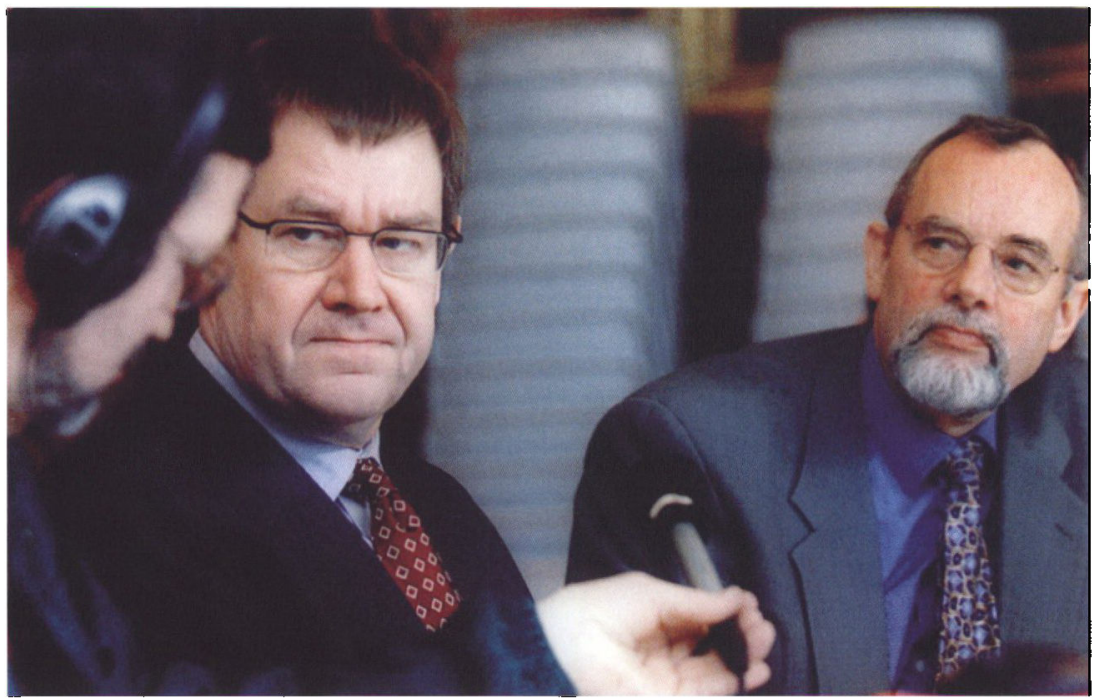

Interview med statsminister Poul Nyrup Rasmussen $i$ Sonderborg $i$ 1990'erne. Til højre formand for Bund Deutscher Nordschleswiger, Hans Heinrich Hansen. Foto $i$ prizateje.

der føler sig lidt overset. Men hjemmetyskerne ville ikke have den Stellenwert, de har i dag, hvis ikke det havde været for Matlok.

Siger man Matlok, siger man også uvilkårligt Peter Iver Johannsen. Han var generalsekretær for det tyske mindretal i perioden 19732008 - og hans indsats for mindretallet står ikke i skyggen af Matloks. Johannsen har været hjemmetyskernes stoute samlingspunkt - og ham har jeg ofte gjort brug af, når jeg manglede baggrundsviden. Han er heller aldrig veget tilbage, når jeg holdt mikrofonen frem med ordene: "Sag was, Peter Iver«.

Som journalist er man altid på jagt efter det væsentlige. Og når det drejer sig om mindretal, ligger temaer som identitet og sindelag helt i top. Derfor vakte det opsigt i det tyske mindretal, da jeg i 2007 interviewede direktøren for LHN, Landwirtschaftlicher Hauptverein für Nordschleswig, Astrid Donnerborg. Her forsøgte hun at nedtone det tyske element $\mathrm{i}$ foreningen ved at sige, at "vi har også mange andre medlemmer end tyske«. Selvom udtalelsen var den rene og skære sandhed, blev udtalelsen taget ilde op i mindretallets top. Der var voldsom aktivitet i kulisserne - og efter knap otte måneder som 
direktør var Astrid Donnerborg fortid i LHN. Visse ting skal man holde sin kæft med, også selvom de er sande. Officielt havde direktørens exit dog ikke noget med hendes udtalelser i Radio Syd at gøre.

Danske og tyske har $\mathrm{i}$ de seneste årtier for alvor rakt ud efter hinanden i grænselandet, således også på Dybbøl hvert år den 18. april. Uden en egentlig debat mellem flertal og mindretal eller de foreninger, man i øvrigt kunne rådføre sig med i den slags anliggender, besluttede en håndfuld personer at gøre den årlige mindedag for begivenhederne i 1864 til et fælles dansk-tysk anliggende. Det har det så været $\mathrm{i}$ en halv snes år nu - uden min deltagelse. Måske skulle jeg møde op til næste år og tilgive, at en prøjsisk kugle sårede min tipoldefar under »Stormen« 18. april, så han døde 12 dage senere på Kronborg Lazaret.

Når jeg ironiserer en smule, hænger det sammen med den holdning, jeg har til disse ting. Man behøver jo ikke ligefrem at lave alting om i grænselandet for at bevise, hvor meget vi respekterer hinanden. Man kan jo udmærket - som jeg gør i hverdagen - betragte tyskerne som gode og ligeværdige naboer uden absolut at skulle stå skulder ved skulder med hinanden på Dybbøl 18. april. Var jeg et mindre pænt menneske, ville jeg måske spørge, om vi måske også snart skal til at mindes 9. april 1940 skulder ved skulder med tyskerne i Hokkerup, Søgård og Bredevad hvert år ...

Jeg vil heller ikke undlade at give det grænseoverskridende samarbejde et par ord med på vejen. Siden oprettelsen i 1997 af Region Sønderjylland-Schleswig og godt en halv snes år frem, har jeg fulgt næsten samtlige offentlige møder i regionalrådet. Det har ikke overbevist mig om, at dét samarbejde flytter noget af betydning. Bevares lidt er da sat i gang, men det er ikke nær nok.

Sygehussamarbejdet og den tyske redningshelikopters indsats $\mathbf{i}$ Danmark, der er helt unikke områder at samarbejde på, har regionalrådet ikke haft stor indflydelse på. Det samarbejde på græsrodsniveau, der er vokset frem de senere år, er også sket stort set uden Region Sønderjylland-Schleswigs medvirken. Her er danske og tyske virkelig ved at finde hinanden på områder som f.eks. brandslukning, byfester, ringridning og lignende. Alt sammen gode, folkelige aktiviteter, som borgerne kan identificere sig med. Kun hvad angår pendler-rådgivning har Region Sønderjylland-Schleswig virkelig flyttet noget. Og det skal ikke underkendes. 


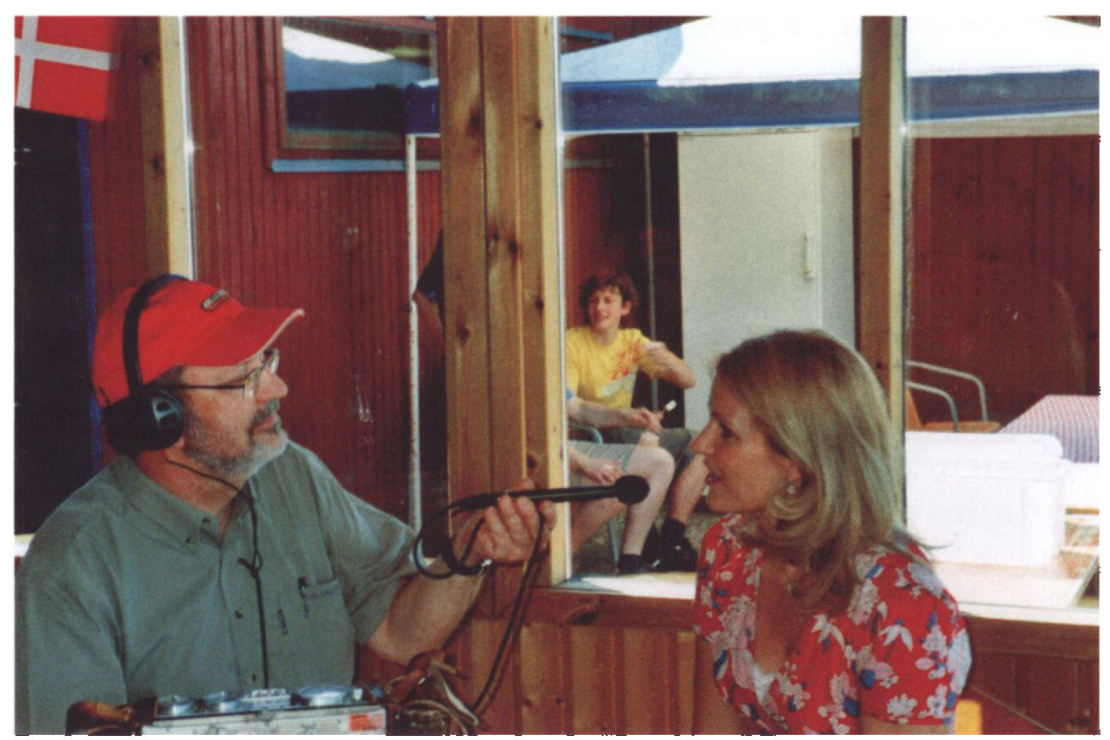

Det er tradition, at danske politikere taler og bringer hilsener til de danske sydslesvigere ved årsmoderne $i$ Sydslesvig. Radio Syds grænselandsmedarbejder er også på pletten - og interviewer her socialdemokraternes formand Helle Thorning-Schmidt ved årsmedet $i$ Hatsted ved Husum $i$ 2006. Foto i privateje.

\section{Karl Otto og andre personligheder syd for grænsen}

Tager vi syd for grænsen, har jeg også på det nærmeste vadet rundt mellem spændende og indflydelsesrige mennesker. I tilfældig rækkefølge vil jeg nævne Karl Otto Meyer, Anke Spoorendonk, Heinrich Schultz, Dieter Küssner, Gerda Eichhorn, Rolf Lehfeldt, Sophie B.Jensen, Dieter Lenz, Emil Schröder, Silke Hinrichsen, Edith Sigaard-Madsen, Nis Hardt, Else Fanø, Henry Buhl, Thyra Feil, Flemming Meyer, Andreas Lorenzen og Henrik Becker-Christensen. Også denne liste kunne forlænges betragteligt.

Mens disse linjer skrives, er Karl Otto Meyer 82 år - og i mange danskeres bevidsthed nord for grænsen er han »Mister Sydslesvig". Han var 55 år, da jeg begyndte i DR. Karl Otto er - i sagens natur en af de danske sydslesvigere, jeg oftest har beskæftiget mig med og interviewet. Som landdagsmand for SSV havde den utrættelige Abgeordnete Meyer stor indflydelse, og internt i mindretallet har hans holdninger og meninger fyldt meget. Selvom hans samlede indsats - 
også som chefredaktør på Flensborg Avis - nødvendigvis må påkalde respekt, har Karl Otto ikke kun tilhængere i egne rækker. Et menneske, hvis personlighed kan have det med at stjæle noget af lyset fra andre, får ikke kun venner.

Dieter Küssner har siden 2003 været formand for Sydslesvigsk Forening. Højskoleforstanderen fra Jaruplund har efter min opfattelse en fin evne til at sætte ord på »den sydslesvigske historie«. Mest har jeg haft med ham at gøre $\mathbf{i}$ forbindelse med "Grænseland Europa «. Næsten uanset hvilket emne jeg foreslog om europæiske forhold, sagde Küssner altid: »Det kan vi godt spinde en ende over - ikk' Matlok? « Og den ende blev i reglen særdeles lytteværdig. Også i den daglige nyhedsdækning i Radio Syd var Küssner altid parat til at stille op - og han veg heller ikke tilbage, når mine sporgsmål var kritiske og kontroversielle. Samarbejdet med Küssner er noget af det, jeg som efterlønner tænker tilbage på med særlig glæde.

I mine år som grænselandsmedarbejder lærte jeg fire danske generalkonsuler i Flensborg at kende - tre aktive og én forhenværende: Lorenz Rerup, H.P.Clausen, Troels Fink og den nuværende, Henrik Becker-Christensen. Tre af dem er ikke mere, men Henrik BeckerChristensen er heldigvis en sprællevende 60-årig. Han er aktiv og flittig - og den tidligere direktør for Institut for Grænseregionsforskning udfolder med succes store bestræbelser på at udbygge den mellemfolkelige forståelse i grænselandet.

\section{Og flertallet ...}

Skal jeg sige lidt om personligheder fra den danske flertalsbefolkning, som jeg har mødt og interviewet i mit arbejde for DR, er der bl.a. en hel stribe forhenværende og nuværende toppolitikere: Anker Jørgensen, Poul Nyrup Rasmussen, Anders Fogh Rasmussen, Helle Thorning-Schmidt og Pia Kjærsgaard. Desuden flere håndfulde folketingsmedlemmer, i flæng kan jeg nævne Kaj Ikast, Frode Sørensen, Helge Mortensen, Kim Mortensen, Laurits Tørnæs, Ulla Tørnæs, Henrik Dam Kristensen, Peter Christensen, Peder Sønderby og Ellen Trane Nørby. Regionale politikere har også svært ved at sige nej til at komme i radioen, det gælder f.eks. Kresten Philipsen og Carl Holst, som jeg har stillet mange spørgsmål til.

Andre, hvis navne mange nikker genkendende til, og som jeg også 
har interviewet, er f.eks. Asger Reher fra Ørkenens Sønner, Jesper Bank, Ole Olsen, TV-kommentator Poul Hansen, Søren Lerby, Lars Christiansen, Trine Gadeberg, Inge Adriansen, Thorkild Kjærgaard, Peter Gæmelke, Anders Dahl Nielsen, Henrik Skov Kristensen, Helge Engelbrecht, Ebbe Sand, Hans Schultz Hansen, Gert Karkov, Anders Bondo Christensen, Søren Brix Christensen og Conny HamannBoeriths - listen kunne fylde flere sider.

\section{"Som et dyr i Zoologisk Have! «}

Den kongelige familie - og lensgreve Hans Schack på Schackenborg har også haft min bevågenhed som journalist. Sammen med min daværende kollega, Inger Bach, interviewede jeg prins Joachim i marts 1988, da han var sergentelev på Sønderborg Kaserne. Da interviewet var "i kassen", havde jeg ikke forestillet mig, at det ville komme til at præge - og i en vis udstrækning rydde forsiden på mange aviser, bl.a. B.T., Ekstra-Bladet og Politiken. "Jeg er som en abe i bur«, blev prinsen citeret for på Ekstra Bladets kæmpemæssige plakat. På B.T.s hed det: "Joachim støtter bønderne« - og så med "dommedagstyper «: "Stop den hetz«. Adskillige aviser skrev ledere om indholdet af vores udsendelse, og fra en artikel i Vejle Amts Folkeblad citerer jeg i flæng: "Vi spiser definitivt dårligt her på kasernen. Så vidt jeg ved, er maden kun dårligere i Odense. Sagde en åbenhjertig prins Joachim i et interview i går i Radio Syd. Sønderjyderne er meget hengivne overfor den kongelige familie. Det varmer mig meget. Jeg kan gå mere diskret ud her end i København. Jeg vænner mig aldrig til at blive behandlet ikke som et menneske, men som et dyr i zoologisk have".

Jo - Ingers og mit interview med prinsen var et scoop, der gav anledning til avisartikler adskillige dage efter den 9. marts 1988. Således ytrede blandt andre Ebbe Kløvedal Reich, Birte Weiss, Anders Andersen og Flemming »Bamse« Jørgensen sig fire dage senere $\mathrm{i}$ Ekstra Bladet om Joachims udtalelser til Radio Syd. Og vores chef, Frode Kristoffersen, var glad: "Jeg skal love for, at den har givet flot bingo - den med Joachim - til lykke med det", hed det i det maskinskrevne brev, Inger og jeg og vores tekniske chef, Flemming Biehl Hansen, modtog fra Frode. Det var Biehl Hansen, der optog interviewet.

Dronning Margrethe har jeg talt med et par gange, dels under private former i Skagen for år tilbage, dels som udsendt af Radio Syd i 


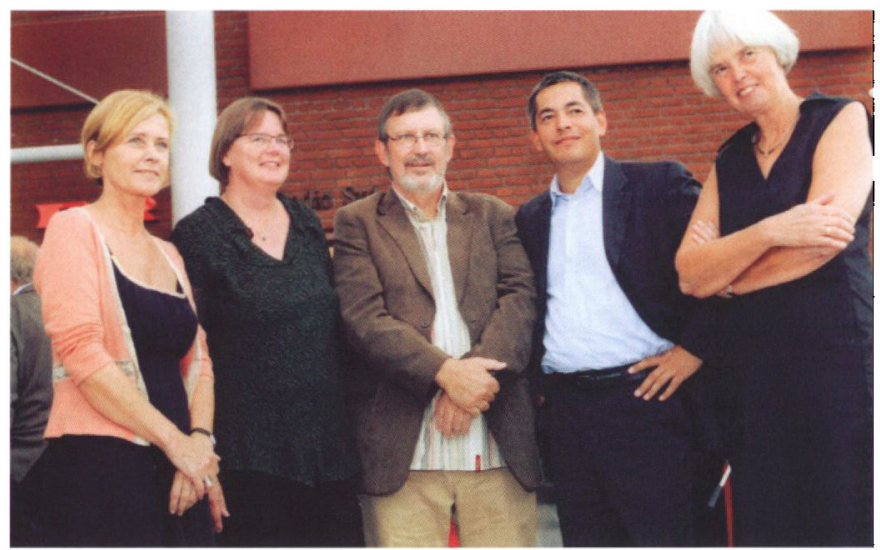

Kort for sit 25-års jubilaum på Danmarks Radio takkede Flemming Nielsen af $i$ 2008. Han ses her ved afskedsreceptionen mellem til venstre Mette Bock og Anette Johnsen - og til hojre Kenneth Plummer og Inger Bach. Foto i privateje.

november 1987 i Haderslev. Herfra citerede Billed-Bladet: "En medarbejder fra Radio Syd stillede Margrethe følgende spørgsmål: »Er det ikke lidt mærkeligt at være med til at udsmykke en kirke, når der ikke kommer så mange mennesker?« Margrethes svar kom som et piskesmæld: »Den slags spørgsmål stilles oftest af dem, som ikke selv går i kirke«. Den bemærkning vakte stor moro, og Radio Syds velmenende medarbejder luskede bort med røde ører«. Og denne medarbejder var altså mig. Men jeg luskede altså ingen vegne.

Prinsesse Benedikte berettede jeg første gang om på Gråsten Rådhus $i$ juni 1968, da hun og prins Richard blev modtaget af borgmester Sven Kjems. Dagen efter citerede jeg prinsessen for følgende i Sønderjyden: »Det er første gang, jeg har min mand med til Gråsten, men vi vender tilbage, når far og mor kommer herned og holder ferie i juli«. Benedikte berettede jeg om mange år senere for radioen, da hun besøgte spejderlejren Blå Sommer ved Hostrup Sø syd for Aabenraa.

Jeg fik en solohistorie på bånd, da jeg ledsagede prins Joachim og prinsesse Alexandra, mens de under et besøg i Sydslesvig fik forevist Danevirke Museum. Alle mine kolleger måtte pænt vente udenfor. Jeg overtalte SSF-formand Heinrich Schultz til at smugle mig ind ad en bagdør efter at have brokket mig højlydt. Det var nemlig umuligt at lave en radioreportage om et kongeligt beseg, når jeg opholdt mig på en parkeringsplads, og prinsessen og prinsessen var inde på museet. 


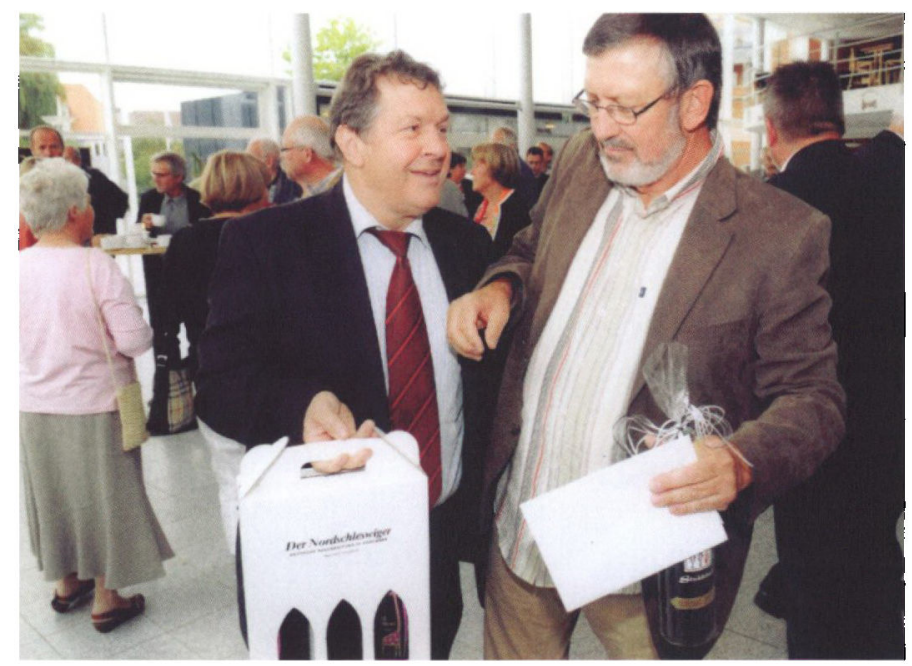

"En loyal og dog kritisk journalist", skrev Bund Deutscher Nordschleswiger $i$ et telegrain om Flemming Nielsen. Chefredaktor Siegfried Matlok fra Der Nordschleswiger takker $i 2008$ for samarbejdet. Foto i privateje.

Kongestoffet har jeg også dyrket flere gange i Gråsten, hvor jeg fik tilladelse til - $i$ et par programmer - at tegne en slags portræt i radioen af Gråsten Slot. Her medvirkede bl.a. slotsgartner Per Bendt Moseholt og flere andre af slottets ansatte.

Lensgreve Hans Schack mødte jeg et par gange på hans "hjemmebane", Schackenborg i Møgeltønder. Dels da han berettede om, hvordan man holdt jul på slottet, dels i forbindelse med "Folkegaven« til Joachim og Alexandra. Under en tur i slotsparken hev jeg mikrofonen frem for at stille et par spørgsmål til Bitten Clausen fra Danfoss. Hun fulgtes med daværende amtsborgmester Kresten Philipsen. Fru Clausen kiggede en smule skræmt på mig - og det resulterede i, at Kresten tog piben ud af munden og sagde: "Snak du kun med ham, Bitten - det er bare Flemming fra Radio Syd «. Og så fik jeg mit interview.

\section{De skal ikke blive glemt, de gamle foreninger}

Danmarks Radio er en arbejdsplads på godt og ondt, hvor man - ligesom på de fleste andre mediearbejdspladser - gor en masse for at finde ud af, hvad brugerne efterspørger. Hvilken slags musik vil lyt- 
terne høre - hvor lange skal indslagene være - hvad slags nyheder interesserer lytterne osv. Som medarbejder er man ikke altid enig i den linje, der bliver lagt. Men naturligvis er man loyal.

Som grænselandsmedarbejder har jeg mest støttet mig til min egen dømmekraft. Hvis det var endt i plenum, om det var relevant at bringe den og den nyhed fra den og den begivenhed, var jeg nok indimellem blevet underkendt. Væsentlighedskriteriet på Radio Syd er jo ikke anderledes end på Nordjyllands Radio, men deroppe har de heller ikke et grænseland med mindretal og den slags. Jeg har altid insisteret på, at vi som Danmarks Radio også var forpligtet til at følge med i, hvad der rørte sig i foreninger som Historisk Samfund for Sønderjylland, Grænseforeningen, Sprogforeningen, Landeværnet og andre lignende foreninger. De afspejler på mange områder grænselandets historie og udvikling, og det er også en public-service-forpligtelse at berette om deres virke. I godt tolv år var min chef på Radio Syd, Tharben Hansen, altid ivrig efter at agere sparringspartner på grænselandsstoffet. Han er tøndring med en journalistisk fortid på bl.a. Flensborg Avis.

Som journalist har jeg altid været bevidst om ikke at sammenblande arbejde og personlige interesser. Det har ikke altid været uden omkostninger. Således er jeg kun i meget beskedent omfang kommet privat sammen med folk, der jævnligt optrådte i mine programmer/ indslag. Da vore børn var små, måtte de ikke deltage $\mathrm{i}$ konkurrencer i radioen. Min bror spillede i orkester i mange år, og de udgav en halv snes kassettebånd. De blev aldrig spillet, når jeg bestemte musikken. Jeg var kun medlem af en enkelt forening, Grænseforeningen, et medlemsskab, jeg tegnede længe før jeg vendte tilbage til Sønderjylland. Ingen skulle kunne sige, at bestemte foreninger havde fordel af at have grænselandsmedarbejderen som medlem. Men efter at jeg forlod DR, er jeg nu også medlem af Historisk Samfund og Sprogforeningen. Behovet for at være uafhængig $\mathrm{i}$ årene som aktiv journalist bevirkede også, at jeg - trods stor politisk interesse - aldrig meldte mig ind $i$ et politisk parti.

\section{Andre nyheder}

Heldigvis gik det ikke kun op i Landdag og mindretal og den slags $\mathrm{i}$ mine år som grænselandsmedarbejder. Indimellem var der også tid til at dyrke et par »nicher«. I adskillige år gjorde jeg meget ud af at 
berette om det smugleri af gods og mennesker, der foregik - og foregår - over grænsen. Smugleri af narko og spiritus i store mængder er "godt stof ". Vi mennesker elsker at høre, at andre er blevet knaldet med 286 flasker spiritus og nu skal af med en mindre formue i afgift og bøde. Og hvad med hollænderen, der havde gemt et større kvantum narko i bilen, men blev afsløret af en kvik narkohund? Præventivt tror jeg, det har stor betydning at berette om disse ting. Det er en katastrofe, at Skat er så passiv, når det gælder om at informere om f.eks. smugleribekæmpelse.

Kunst er en anden »niche«, jeg har dyrket lidt. Den stod kollegerne ikke ligefrem i kø for at tage sig af på Radio Syd, måske fordi det kan være svært at beskrive et kunstværk i radioen. På grund af min helt personlige kunstinteresse, der blev grundlagt i Skagen, var det ofte min opgave at interviewe billedkunstnere som Hans Tyrrestrup, Bjarke Regn Svendsen, Aage Schmidt, Ole Prip Hansen og Hans Lembrecht Madsen. Det havde jeg - og forhåbentlig også lytterne - stor fornøjelse af.

Jeg var kun 60 år, da jeg sagde farvel til arbejdsmarkedet i 2008 efter næsten 25 år i DR. - „Er du tosset, du ka' sgu da ikke undvære radioen og kollegerne«, sagde mange til mig. Men det går nu helt godt. Hellere forlade et job, mens du holder af det end vente, til du er træt af det. Det var jeg nået frem til. Og efter godt 43 år som journalist var det også på sin plads at finde ud af, om jeg kunne finde en mening med tilværelsen UDEN at skulle køre til Aabenraa hver dag. Det er lykkedes over forventning.

\section{Spot på budbringeren}

Selvom jeg har haft det bedst med at sætte spot på - og berette om andre mennesker, har jobbet medført, at der også har været spot på budbringeren (læs: »mig«) indimellem. I 2006 modtog jeg en mindretalspris af Flensborg Avis, Der Nordschleswiger, Sydslesvigsk Forening og Bund Deutscher Nordschleswiger. Det skete på Knivsbjerg samtidig med et møde i MIDAS, Sammenslutningen af mindretalsaviser i Europa. Ved den lejlighed hilste jeg på ingen ringere end Otto von Habsburg, søn af Østrigs sidste kejser.

Året før - i 2005 - udgav dansk og tysk postvæsen et særfrimærke i anledning af 50-året for København-Bonn-erklæringerne. Ved et arrangement i Harreslev blev der overrakt flotte særtryk til »udvalgte 
danske og tyske", som Sydslesvigsk Forening skrev. Og en af de udvalgte var altså mig, der modtog hæderen af den særdeles omdiskuterede slesvig-holstenske politiker, Ralf Stegner, og statssekretær i Berlin, Franz Tönnies.

Som om det var i går, husker jeg min første arbejdsdag på Radio Syd i 1983. Det samme kan jeg sige om den sidste i 2008. Da kom mange kolleger og kilder og private venner og hjalp mig med at sige pænt farvel til DR, en rigtig god arbejdsplads. Én af de fremmødte var generaldirektør Kenneth Plummer, der dog var til møde i Aabenraa alligevel. Adskillige mennesker, bl.a. Inger Bach, sagde pæne ting til mig ved dén lejlighed, ord, der gjorde mig glad. Bund Deutscher Nordschleswiger skrev i et telegram bl.a., at man "med bedrøvelse sagde farvel til en loyal og dog kritisk journalist ...«

Og de ord rummer vel, hvad jeg har bestræbt mig på at være som journalist i forhold til lyttere, læsere og kilder: Loyal - men også kritisk.

\section{Zusammenfassung}

25 Jahre lang, von 1983 bis 2008, konnte man die charakteristische, sønderjysk-geprägte Stimme des Journalisten Flemming Nielsen auf Radio Syd hören. Nielsen war unter anderem Gastgeber der populären Programme "Grenzland «, »Grenzland Europa « mit Siegfried Matlock und Dieter Küssner als regelmäßigen Gästen, sowie dem Programm "Zwei Generationen «. Besonders interessiert in seiner journalistischen Tätigkeit beim Radio haben ihn die beiden Minderheiten. Das journalistische Handwerk erlernte er an der Westküste in Tønder sowie bei der Zeitung Sønderjyden in Sønderborg Ende der 1960er. Flemming Nielsen berichtet von seinen vielen Jahren als Journalist im Grenzland, von seinen Arbeitsplätzen und von den vielen Menschen, die er traf. 